\title{
Remembering the Sea: Personal and Communal Recollections of Maritime Life in Jizan and the Farasan Islands, Saudi Arabia
}

\author{
Dionisius A. Agius ${ }^{1} \cdot$ John P. Cooper ${ }^{1} \cdot$ Lucy Semaan $^{2} \cdot$ \\ Chiara Zazzaro ${ }^{3} \cdot$ Robert Carter $^{4}$
}

Published online: 22 June 2016

(C) The Author(s) 2016. This article is published with open access at Springerlink.com

\begin{abstract}
People create narratives of their maritime past through the remembering and forgetting of seafaring experiences, and through the retention and disposal of maritime artefacts that function mnemonically to evoke or suppress those experiences. The sustenance and reproduction of the resulting narratives depends further on effective media of intergenerational transmission; otherwise, they are lost. Rapid socio-economic transformation across Saudi Arabia in the age of oil has disrupted longstanding seafaring economies in the Red Sea archipelago of the Farasan Islands, and the nearby mainland port of Jizan. Vestiges of wooden boatbuilding activity are few; long-distance dhow trade with South Asia, the Arabian-Persian Gulf and East Africa has ceased; and a once substantial pearling and nacre (mother of pearl) collection industry has dwindled to a tiny group of hobbyists: no youth dive today. This widespread withdrawal from seafaring activity among many people in these formerly maritime-oriented communities has diminished the salience of such activity in cultural memory, and has set in motion narrative creation processes, through which memories are filtered and selected, and objects preserved, discarded, or lost. This paper is a product of the encounter of the authors with keepers of maritime memories and objects in the Farasan Islands and Jizan. An older generation of men recall memories of their experiences as boat builders, captains, seafarers, pearl divers and fishermen. Their recounted memories are inscribed, and Arabic seafaring terms recorded. The extent of the retention of maritime material cultural items as memorials is also assessed, and the rôle of individual, communal and state actors in that retention is considered. Through this reflection, it becomes clear that the extra-biological memory and archive of the region's maritime past is sparse; that intergenerational transmission is failing; that the participation
\end{abstract}

John P. Cooper

j.p.cooper@exeter.ac.uk

1 Institute of Arab and Islamic Studies, University of Exeter, Exeter, UK

2 Department of Archaeology and Museology, Institute of History, Archaeology and Near Eastern Studies, University of Balamand, Koura, Lebanon

3 Department of Asia, Africa and the Mediterranean, University of Naples 'l'Orientale', Naples, Italy

4 University College London-Qatar, London, UK 
of state agencies in maritime heritage creation is highly limited; and that, as a result, memories current among the older generation have limited prospect of survival. These memories, recorded and interpreted here, identify the Farasan Islands as a former centre of the pearling industry in the Red Sea, and identify them and Jizan as open to far-reaching maritime-mediated cultural influences in an era before the imposition of the attributes of the modern nation-state.

Keywords Farsan Islands · Jizan - Red Sea - Saudi Arabia - Maritime culture $\cdot$ Pearling industry $\cdot$ Dhow $\cdot$ Boat-building $\cdot$ Memory $\cdot$ Heritage

\section{Introduction}

"[W]e do not remember the past," cautions the intellectual historian Allan Megill (2007: 54), "We 'remember' what remains living within our situations now." For the communities of Saudi Arabia's Farasan Islands (جزر فرسان) in the southern Red Sea and in the nearby mainland port-city of Jizan (جيزان), "what remains" is in a process of rapid diminution. Fundamental economic, social, technological and political change over the last eight-or-so decades has seen the abandonment of long-standing maritime practices. The growth of the Saudi state and associated economy, particularly since the early 1970s, has introduced alternative ways of making a living. These have replaced former activities such as pearling, which fell afoul of the emergence of the culture-pearl industry from the 1920s onwards; tramping and longdistance trade in wooden vessels, which gave way to road-transportation and modern shipping; and fishing, which could not compete on its former scale with the employment attractions of a modernising economy, not least the oil industry concentrated in the country's Eastern Province. The "situation" of remembrance is therefore one in which dwindling numbers of first-hand participants in former maritime activities and landscapes survive. Alongside the fading of this "biological memory" (Donald 1991: 308), so too the material remnants of the maritime past are disappearing, whether through what cultural theorist Aleida Assmann (2010: 97-98) calls active forgetting - in the form of "trashing and destroying"-or more commonly through passive forgetting, in which she includes "losing, hiding, dispersing, neglecting, abandoning or leaving something behind."

In Jizan and the Farasan Islands, remembrance of the maritime past resides largely, though not entirely, in the realm of the individual and the informal. This is often through passive, biologically held memory that does not always find occasion to be shared within families and communities into the longer-lived "collective" or "communicative" spheres of memory, as Jan Assmann calls them (1995: 126). The "living on" of these memories, as he argues (1997: 10), depends on "the continuous relevance of these events." Local historian Ibrahim Muftah (Fig. 1b) has committed his narrative history of the islands to book form, in Farasān: Al-nās, al-baḥr, wa l-tārīkh (2005), or Farasan: the people, the sea and history, and is followed in that direction by the present authors' contribution. However, if "generations and families are media of memory" (Olick et al. 2011: 312), then much stands to be lost, since it is far from clear that a widespread intergenerational transmission of seafaring knowledge, memory, and material culture is taking place within formerly maritime communities amid the distractions and preoccupations of the new reality. Certainly it 

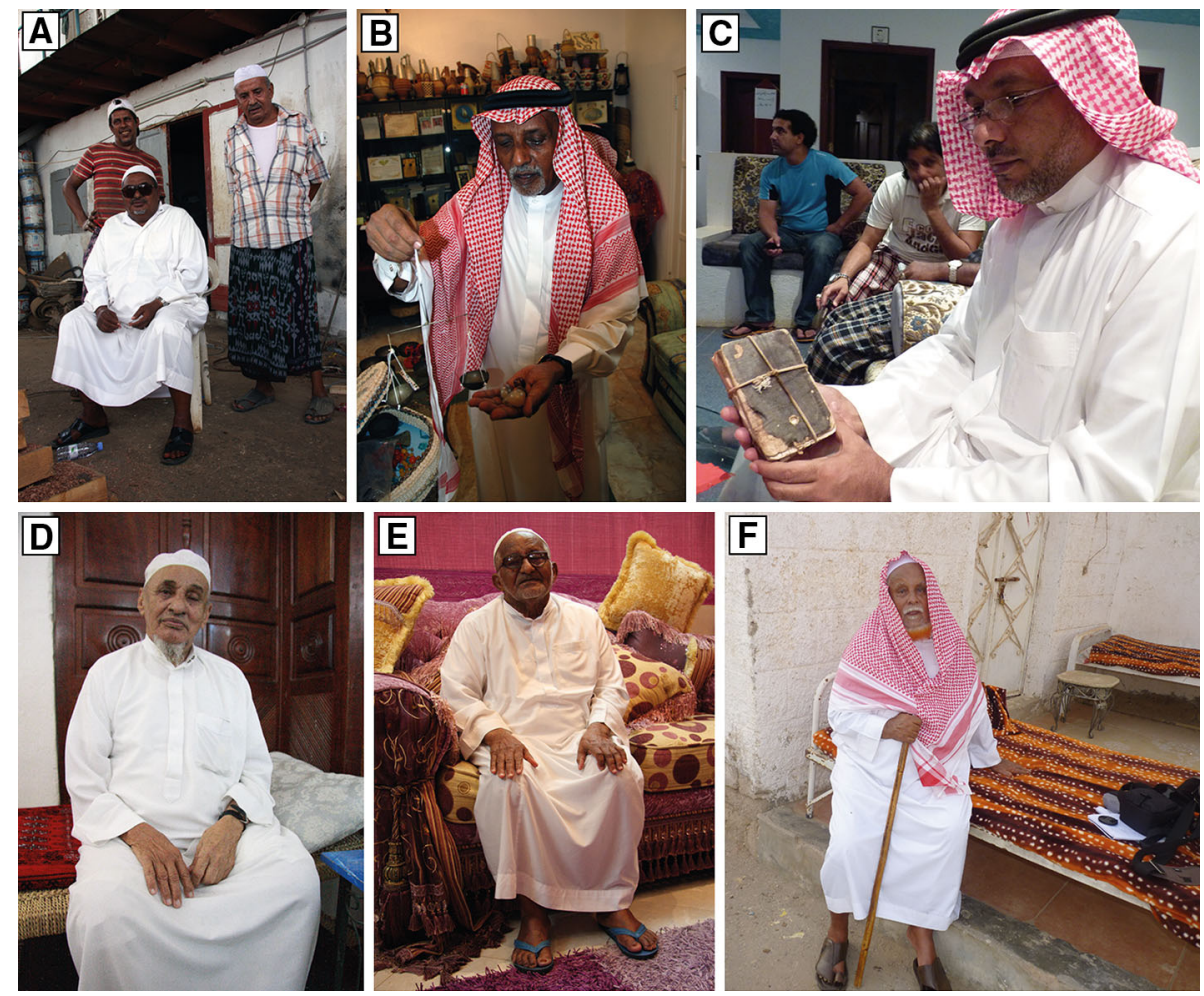

Fig. 1 Remembering the sea: a Ibrahim Bilghaith (seated), boatbuilder at al-Hafa, Jizan. His assistant (and model builder) Muhammad Hadrami Abdo is at his right shoulder (Image: J. P. Cooper); b Farasan Islands historian Ibrahim Muftah (Image: Peter Harrigan); c Muhammad al-Rajhi, Sheikh of Farasan, with his 1928 chao book (Image: D. A. Agius); d Former captain and sanbūk-owner Sheikh Yahya Ibrahim Al Najdi Al Tamimi, Farasan town (Image: J. P. Cooper); e Former pearl diver Muhammad Isa Muhammad Aqili, Farasan town (Image: J. P. Cooper); f Muhammad Abd Allah Al Rajhi, Sheikh of Khutub village, Segid island (Image: D. A. Agius)

is no longer the case that "( $\mathrm{t}$ )he training of apprentices and the preservation of craft secrets are taken care of within each of the ... social cells," as Leroi-Gourhan (1993: 259) requires. And there are no public government archives on the islands.

At the same time, governmental involvement in local maritime heritage creation has been limited. In terms of locally focused heritage, it has taken the form of sponsoring searelated festivals, a museum display in distant Sabya (صبي), and occasional public art installations. Academically, it has facilitated the MARES Project research activity reported here, and other, maritime archaeological activity around the islands (especially Bailey et al. 2007a, b, 2013; Williams 2010), but these have yet to find an outlet into public heritage activities.

However, on the Farasan archipelago itself, informal activities continue to recall the past: a small number of individuals still pearl dive on a small scale and with marginal economic objective; the local boys' primary school has assembled its own museum containing maritime artefacts; and several private individuals maintain collections of material culture related to the maritime past. It is in their active choices, entailing forgetting and remembering, disposing of and retaining, that intangible and material culture is — or is not-making 
the transition from what Aleida Assmann (2010: 335) calls its "original "place in life" into the sphere of communal and familial recollection and retention, and hence into the realm of what might be called heritage.

\section{The Fieldwork}

The authors between them conducted two seasons of ethnographic fieldwork in the port town of Jizan, capital of Jazan province, and in the Farasan Islands in early 2010 at the invitation of the Saudi Commission for Tourism and Antiquities (SCTA). The objective was to investigate through interview and material-cultural study the maritime past of the islands, particularly with respect to the former pearling industry, boatbuilding traditions, navigational practices, folkloric traditions and the language of the sea, but also with an openness to hear other narratives. Our curiosity was piqued by reports of continuing smallscale pearl diving in the islands. In terms of material culture, our focus was on the artefacts that form the mnemonic basis of contemporary remembrance of the maritime past, but also the archaeology of the islands. The latter has been reported elsewhere (Cooper and Zazzaro 2012, 2014). The authors had previously done ethnographic fieldwork in 2009 in Djibouti and Yemen (Agius et al. 2010: 71-84, 2014: 143-158).

The present research was conducted at the port town of Jizan, capital of Jazan province, and on the three inhabited islands of the Farasan archipelago-Greater Farasan, Segid (سقيد)

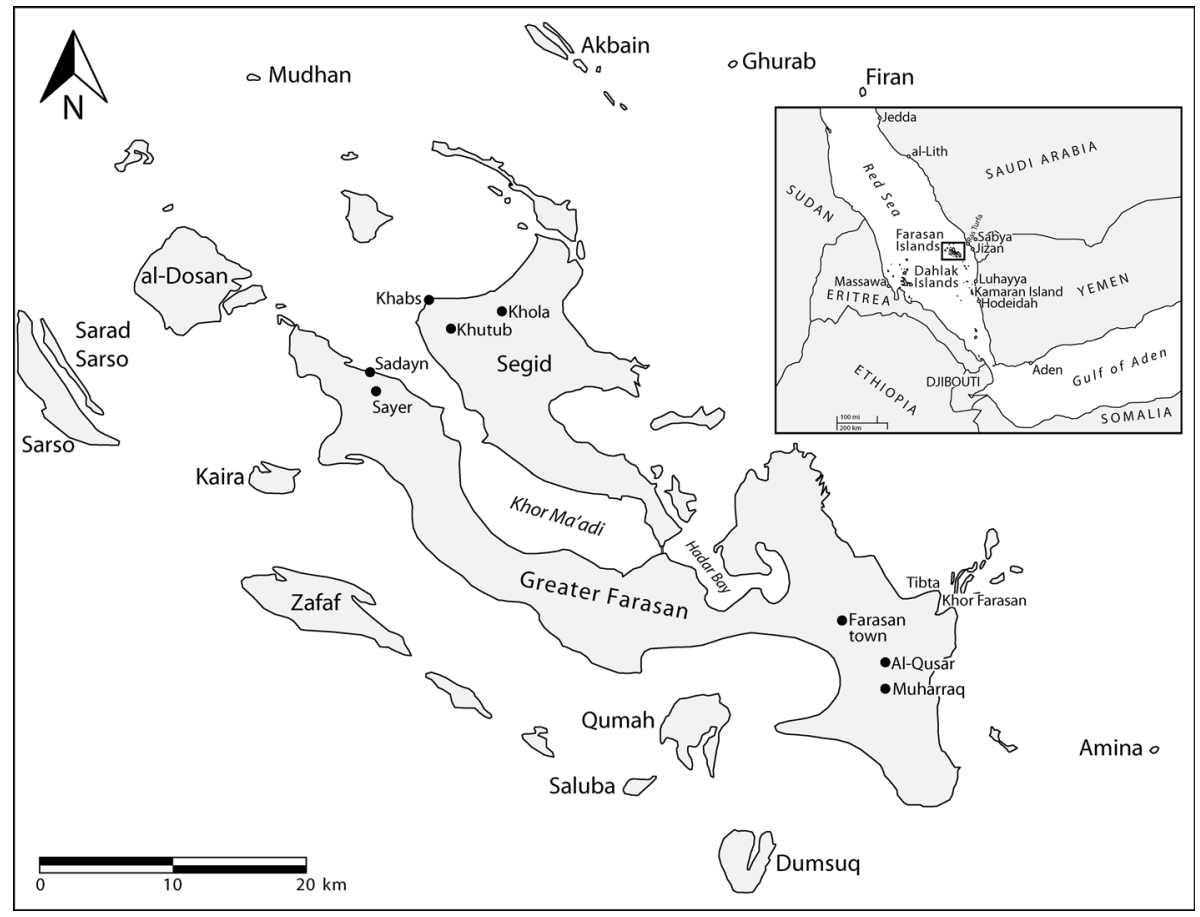

Fig. 2 Map of the Farasan Islands and surrounding region, showing locations discussed in the text. (Image: C. Zazzaro \& J. P. Cooper) 


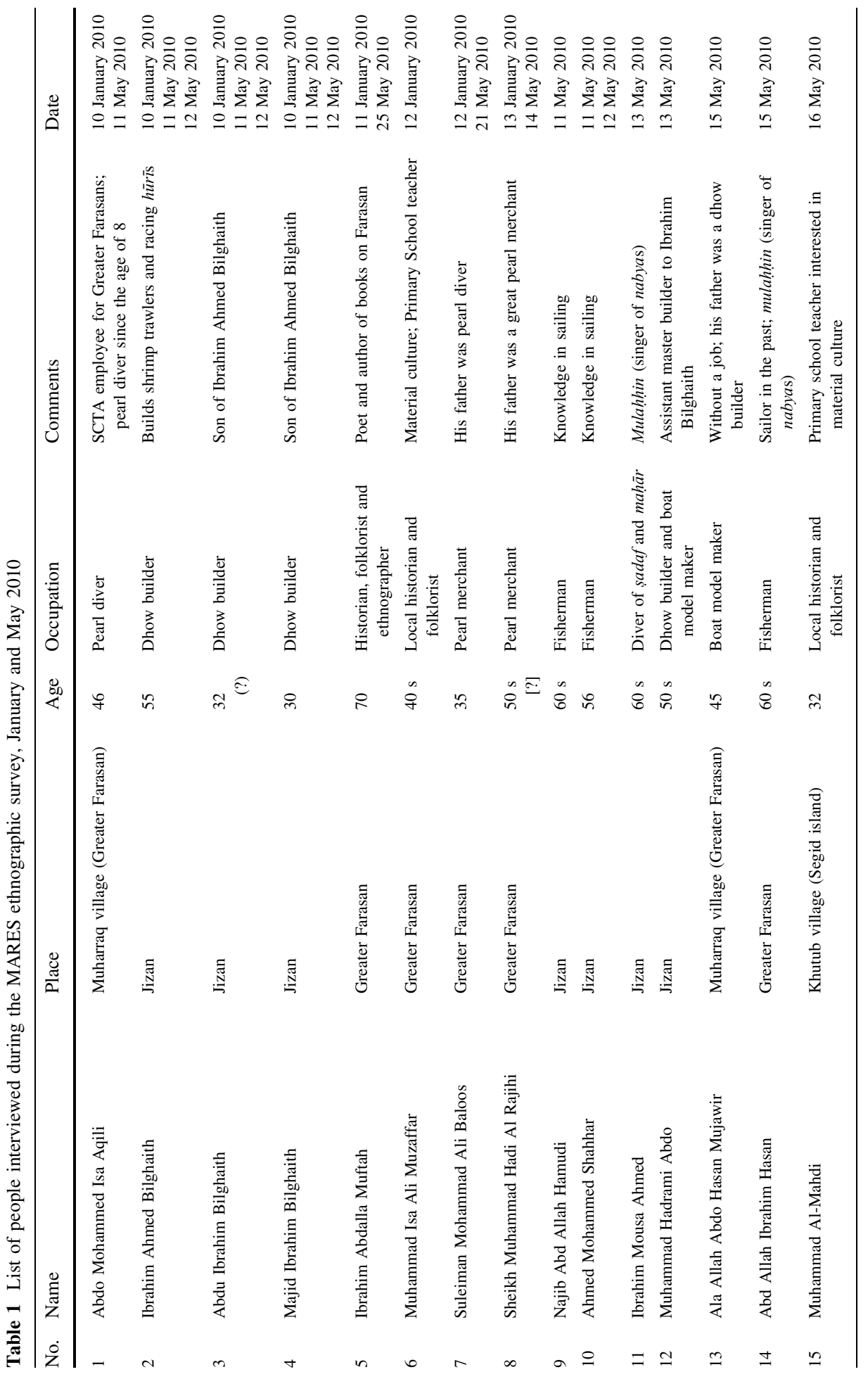




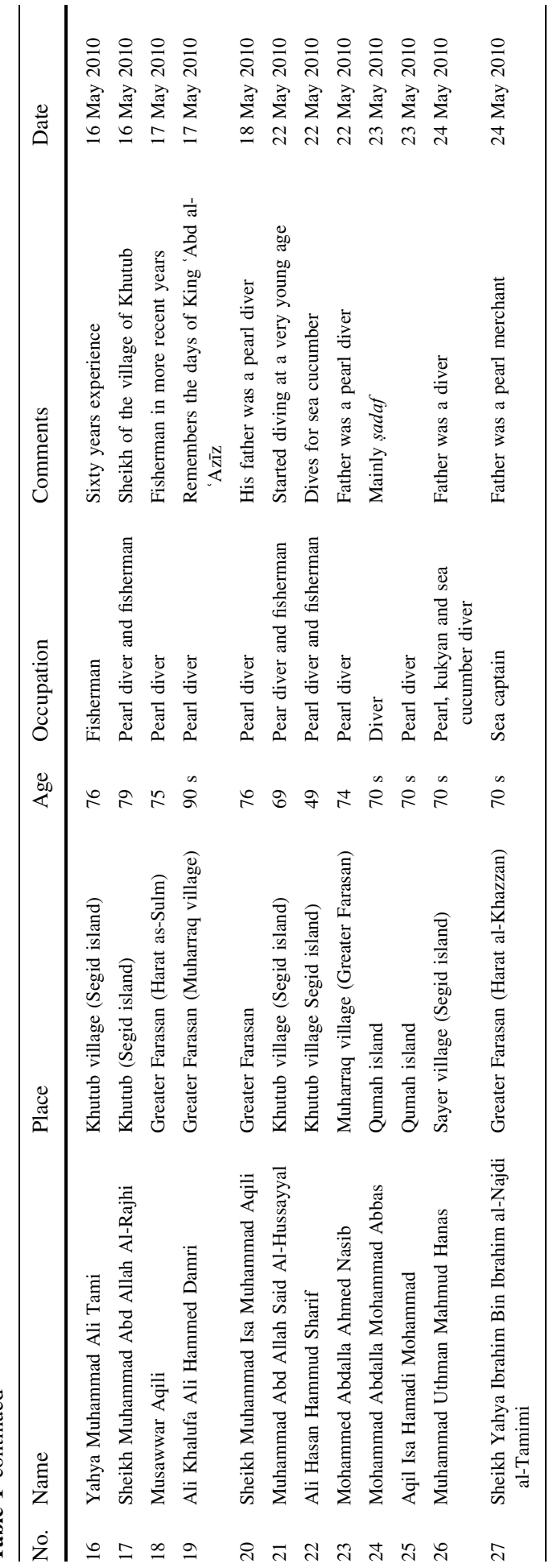


and Qumah (قماح) (Fig. 2). Semi-structured interviews were conducted in Arabic by Agius, Cooper and Semaan; they met a number of people connected with the sea, formerly or currently, to hear their memories. Interviews were conducted with 27 informants: seven from Jizan, and 20 from the Farasan Islands ( see Table 1). The interviewees covered a wide range of ages: one man was in his $90 \mathrm{~s}$, four in their $30 \mathrm{~s}$. About $70 \%$ of those interviewed were retired or almost so. Of those interviewed in Jizan, four were boat builders, two fishermen, and one a pearl diver and fisherman. In the Farasan Islands, one man was an amateur model-boat maker, 13 were former pearl or shell divers and/or fishermen, two were former pearl merchants, one had been a sea captain, and three were local historians and folklorists.

\section{Geographic Context}

Jizan is a port town and regional capital of Jazan province, the smallest and southernmost of Saudi Arabia's provinces, with a population in the 2004 census of 1.2 million (Central Department of Statistics \& Information 2004) (Fig. 2). It offered in the past an open anchorage for vessels travelling between the hinterland and the Hijaz, Yemen, and the wider Indian Ocean. Imports included grains, flour, dates from Basrah (via Aden), sugar and textiles. Coffee, sesame, maize, raisins and butter were exported. Today, modern cargo ships visit it, and it is the ferry port serving the Farasan Islands. A new harbour occupies much of what was a waterfront where formerly sailing ships and boats were built, anchored, hauled up, and repaired. The town is overlooked by the 19th century Dawsaria (دوسرية) fort, and a small number of two-storey merchant houses, built of stuccoed coralstone, remain from when Jizan was involved in the regional coffee trade in the 18th century. In 1921, the town had a population of some 6000 (Anonymous 1946: 545): most men were fishermen, with some pearl divers, and labourers extracting and transporting fertile soil.

The nearby Farasan Islands comprise more than 140 islands and rocky islets formed from uplifted coral, covering a sea area of some $1050 \mathrm{~km}^{2}$ (Fig. 2). ${ }^{1}$ They lie $50 \mathrm{~km}$ west of Jizan and the mainland, and $280 \mathrm{~km}$ from Eritrea on the African littoral. The archipelago mirrors along the axis of the sea Eritrea's Dahlak Islands, with which it has historic links.

The islands are largely flat, with a maximum altitude of $70 \mathrm{~m}$, and the climate arid (ElDemerdash 1996: 82). Underground water sources are the main sustainers of the islands' limited vegetation, which includes cultivated groves of date palms (nakhl; Phoenix dactylifera L.), as well as various acacias (Fig. 3e) and occasional small stands of doum palm (düm; Hyphaene thebaica (L.) Mart.; Fig. 3a), neem (nīm; Azadirachta indica A. Juss.; Fig. 3d), and the occasional barzüma, the local name of Conocarpus lancifolius Engl. (Semaan 2015: 315; Fig. 3c). ${ }^{2}$ Saline coastal marshes contain stands of white mangrove (shüra; Avicennia marina (Forsk.) Vierh.) and red mangrove (gandal; Rhizophora mucronata Lam.) (El-Demerdash 1996: 83-84). All but the date palms have had boatbuilding applications in the recent past. The surrounding coral reefs support prolific marine resources, and the islands are known for the festival surrounding the annual massing of

\footnotetext{
1 The figure is our own, based on counting features visible on satellite imagery. Hubaylī \& Hubaylī (2010) put the number of "islands" at 83-presumably discounting smaller islets and outcrops. Ibrahim al-Muftah told us there were 1062. The differences are presumably a matter of perception and definition.

2 Tree species are given in English, with their local Arabic and/or scientific names following in brackets on first mention.
} 

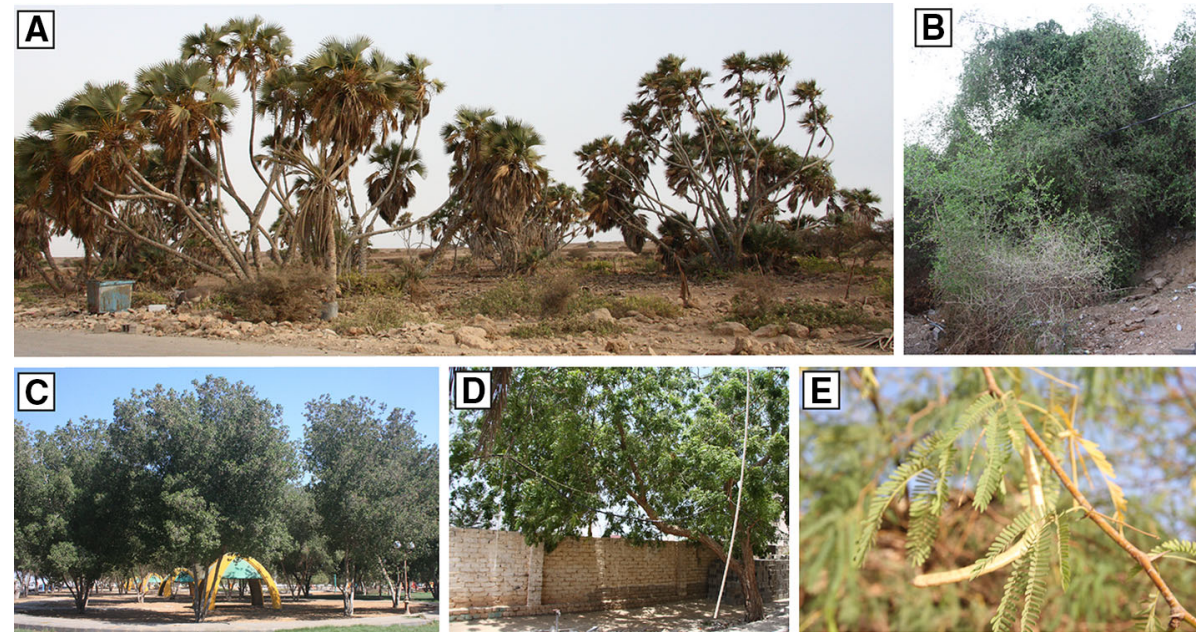

Fig. 3 Local trees: a A grove of doum palm (dūm; Hyphaene thebaica (L.) Mart.) in the village of Khutub; b Christ's thorn jujube growing wild in the urban fringes of Jizan (sidr; Ziziphus spina-christi (L.) Desf.; c Conocarpus lancifolius Engl. (barzūma) planted as shade trees in a public park in Jizan; d Neem (nīm; Azadirachta indica A. Juss.) in the garden of Ibrahim Muftah, Farasan town; e The invasive shajarat al-amīr (Acacia spp.) in the abandoned village of al-Qusar. (Images: J. P. Cooper)

longnose parrotfish (Hipposcarus harid Forsskål) in the shallows of Hadar bay (خليج هدار) (Fig. 2).

Three of the islands-Greater Farasan, Segid and Qumah—are inhabited. A modern bridge connects the first two, and it was on these that most fieldwork was conducted-in Farasan town, Muharraq (صحرّق), Sayer (صيّر) and Khutub (ختب). The more isolated Qumah has a population of some 455 , comprising fishermen and their families. ${ }^{3}$ Until some years ago several were engaged in pearl diving and șadaf (shell) collecting. ${ }^{4}$ Reef species fished today include brown spotted grouper (hāmūr; Epinephelus chlorostigma Valanciennes), roving coral grouper (nājil; Plectropomus pessuliferus Fowler), squaretail grouper (tarād $\bar{l}$; Plectropomus areolatus Rüppell) and emperor fish (sha '̄ur; Lethrinus Spp.). Open-water species include jack (bayā

Sailing conditions along the Arabian coast of the southern Red Sea are generally benign for those who know the complex bathymetry and coastal topography: the numerous channels, islands, reefs and coastal inlets offer shelter for boats. The annual cycle of the monsoon induces winds within the southern Red Sea that assist craft sailing north (on e.g. $a z y a b^{5}$ or khamsinn winds) during the northeast monsoon, and south (on the shamāli wind) during the southwest. Historically, it was this eastern side of the Red Sea-outside the reef zone- that was the recommended route for those heading north, since sailing vessels could take advantage of sheltered waters and southerly winds that last longer than on the African coast (Davies and Morgan 2002: 121). Convenient anchorages are to be found in the south-

\footnotetext{
3 According to Abd Allah Mohammad Abbas, interviewed on 23 May 2010.

4 In standard Arabic, șadaf means 'shell' in a generic sense; our informants used it in a more specific sense, usually to refer to certain varieties of large shell collected for their nacre.

5 Non-English terms in italics are Arabic, unless otherwise indicated.
} 
eastern bay of Segid Island; in Khor Ma'adi (خور sعادي) between Greater Farasan and Segid; and at Qumah Island (Davies and Morgan 2002: 116-117).

The combination of location, shelter and available well water has made the archipelago an attractive stopping off point since antiquity (Cooper and Zazzaro 2014: 149, 165-167). The renowned navigator Ahmad Ibn Mājid (d. 908/1498) sailed to the Farasan Islands in 890/1485 (Tibbetts 1981: 259), and captures something of the navigational landscape of the islands, at least for long-distance sailors. Ibn Mājid describes only the route around the seaward fringes of the archipelago, since "the traveller has no need to visit" those within (Tibbetts 1981: 259). Tibbetts has identified Ibn Mājid's islands of Hundusān and Kadī as Dosan and Kaira respectively (Fig. 2). ${ }^{6}$ North of Hundusān, writes Ibn Mājid, there are islands "having cattle and camels, palms and fruits" (Tibbetts 1981: 259). Moreover, he notes that there is a creek (khōr) where 1000 ships can harbour, and a well, called Shalil, which could supply them. Ibn Mājid's text subsequently describes a route along the northern fringe of the archipelago, and then a broadly southerly trajectory between the islands and the mainland. Comparing Ibn Mājid's text (Tibbetts 1981: 258-260) with Davies and Morgan's Red Sea Pilot (2002: 117), the former's Dhū Salāt and Sāsūh might be associated with the latter's Sarad Sarso and Sarso islands; Șail al-Mațūn island with Mudhan island; the "danger spots" of Rikbain and Ghurab with Akbain and North Ghurab island; Hadhyān or Jabal al-Firān with Firan island; Ras al-Mikhlāf with Ras Turfa on the Arabian mainland; and Amina and its daughters with Amina island and its surrounding islets (Fig. 2). This hints at the place of the islands within the cognitive-navigational landscape of long-distance sailing in the medieval Red Sea, although rather less about how contemporary inhabitants of the archipelago used their landscape.

\section{Remembering the Maritime}

\section{Private Recollections}

People's memories are the major part of what remains locally of traditional maritime activities in Jizan and the Farasan Islands. Our interviews sought the recollections of informants with respect to boat types, wood species used in boatbuilding, pearling activity, journeys taken, seasons, navigation, and life on board. When these were conducted with private individuals, they were usually conducted in their homes, or occasionally at their place of work.

\section{The Last Boatyard}

Yards building and repairing wooden boats existed in the past in both Jizan and the Farasan Islands. Of the many that once dotted the Jizan waterfront at al-Hafa (الحافة), only one survives today - that of Ibrahim Bilghaith, aged 55 when we met him (Figs. 1a, 4b-d). The yard is located alongside Jizan's fishing harbour. We interviewed four boat builders there: Bilghaith himself; his assistant Muhammad Hadrami Abdo, in his 50 s (Fig. 1a); and Bilghaith's two sons Abdo and Majid, both in their $30 \mathrm{~s}$. Ibrahim, who learned the trade

\footnotetext{
${ }^{6}$ Although Tibbetts spells them differently. The spellings here are taken from Davies and Morgan (2002:
} 117). 

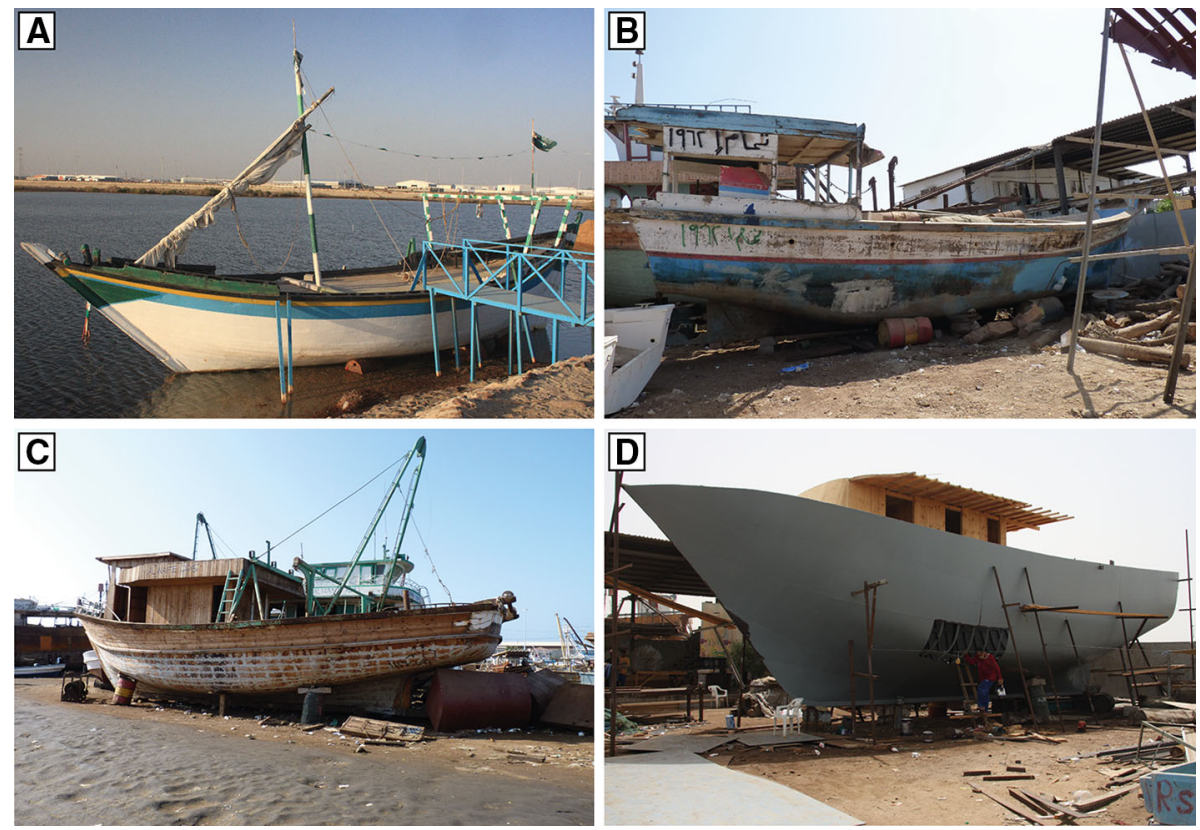

Fig. 4 Vessels built by Ibrahim Bilghaith at his yard in al-Hafa, Jizan: a his last 'obrī, built in the mid-90 s, and now an exhibit at the Suais Heritage Village (Image: J. P. Cooper); b a defunct za ìma of a type built until the mid-90 s (Image: D. A. Agius); c An 'Egyptian'-style fishing boat of a type built at the yard from the mid-90 s until a few months before the MARES fieldwork (Image: D. A. Agius); d a metal-hulled fishing boat (gārib) — the only type built at the yard at the time of the fieldwork (Image: J. P. Cooper)

through his father and grandfather, said that he had built more than 130 vessels there in the space of 10 years, for local buyers and for export to Yemen, Eritrea, Sudan, and occasionally Jeddah. He had built his last wooden vessel in a traditional form, an 'obrī (pl. 'abārì), "over 15 years" previously. He told us construction of 'obrīs had ceased with the exodus of Yemeni guest workers from Saudi Arabia following the 1990 Iraqi invasion of Kuwait: the implication is that Yemeni skilled workers were required to build these double-ended craft, which are "characterized by a straight, raking prow and a stem-post that terminates at or slightly above the sheer line" (Agius et al. 2010: 77). His last 'obrī is now the sole boat exhibited at the Heritage Village at nearby Suais (سويس-Fig. 3a). Bilghaith recalled that he instead started to build quite different, Egyptian-style wooden fishing vessels-one of which was under repair in the yard during the authors' visit (Fig. 5). It was markedly different in its construction from the vessels that had gone before, being frame-first in construction sequence; it owed little to previous boat-building methods at the yard. Some of these Egyptian craft had characteristic rounded counters (Fig. 4c). Initially, Egyptian carpenters had been employed to build them. Bilghaith said they had been introduced in response to the appearance of large metal "Turkish" fishing vessels in the Red Sea at that time. Despite their very novel construction, he continued to call them sanābīk (s. sanbūk), a name that had been transferred from earlier, very different regional types (Hawkins 1977: 58-73). Today, however, Bilghaith observes that local demand had switched to metal fishing vessels (ca. $17.5 \mathrm{~m}$ long by $5.5 \mathrm{~m}$ wide), referred to as gawārib (s. gārib), and used for catching shrimps (rubyān or jurād al-bahar) using seine nets (masāhib). The last of the 

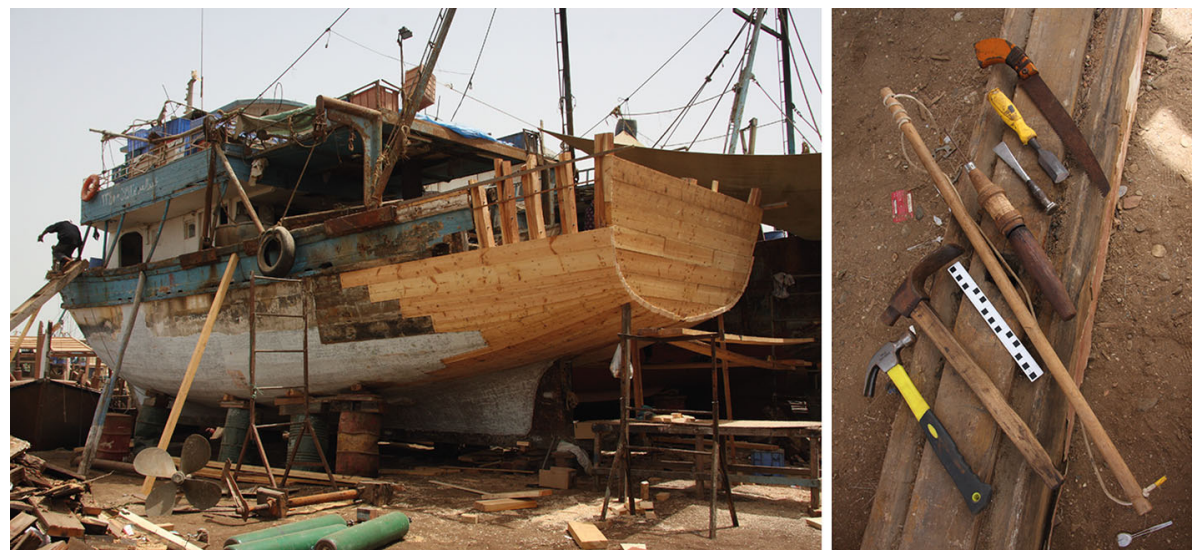

Fig. 5 Left An 'Egyptian'-style fishing sanbūk under repair at the yard of Ibrahim Bilghaith. Right The tool kit of the wooden-boat builder (Images: J. P. Cooper)

"Egyptian" wooden vessels had been completed in the yard only 4-6 months previous to our visit: since then, Bilghaith had shifted focus to concentrate on building such metal vessels in response to changing customer demand (Fig. 4d).

Bilghaith remembered that in the past there had been six boatyards in Jizan. Four of these-owned, he said, by Hassan Jahnun, Ahmad Jahnun, Ali Ibrahim Qasim, and Yahya Ibrahim-had built small plank-built fishing vessels he called hürīs. But his own yard and that of another builder, Abdallah Mubarak Qammash, who had died in his $80 \mathrm{~s}$, had built larger sanbūks, za ìmas (pl. za' āyim) and 'obrīs, in addition to the smaller craft. The $16 \mathrm{~m}$ 'obri preserved at the Suais Heritage Village was the same as examples the authors had encountered in Yemen (Agius et al. 2010: 76-77). However, the sanbūks and za ìmas of Jizan appear to have been quite distinct, at least in their recent incarnations, for which we had evidence: Ibrahim Bilghaith kindly donated to the MARES Project two models, one sanbük and one za ìma, built by Muhammad Hadrami Abdo, which were the only clear indication of what they meant by these terms in this instance. These were made as workshop records, kept as rough reminders of boat types that were no longer built. Both represent single-masted vessels with a transom stern (shanda), full deck, and a central rudder with a tiller (Fig. 6a, b). The raking prow has a slightly convex curve to it. The sterns of both have additional planking about the sheer line that form into two stern-quarter fins extending back beyond the transom stern. What distinguished the models was that the hull of the za 'ima had been adapted to accommodate an inboard motor-though it still had a mast-while the sanbük was represented as a purely sailing vessel. However, Bilghaith also showed us a third model which was distinct from the others in that it had a curved prow that resembled the old ocean-going sanbūks and $s \bar{a}$ iyas of Yemen. He also called this model a za ìma (Fig. 6c).

The relative simplicity of the models leaves some lack of clarity about the nature of the craft on which they were modelled. Bilghaith said that the hull lines of the za ima on which the first model had been based were typically finer than that of the beamier sanbu $k$, though this was not easily discernible from the models. Both types could be of the same tonnage, he said. Meanwhile, they were also clearly distinct in form from those vessels, also called sanbūks and za ìmas, that the authors had encountered in Yemen and Djibouti (Agius et al. 

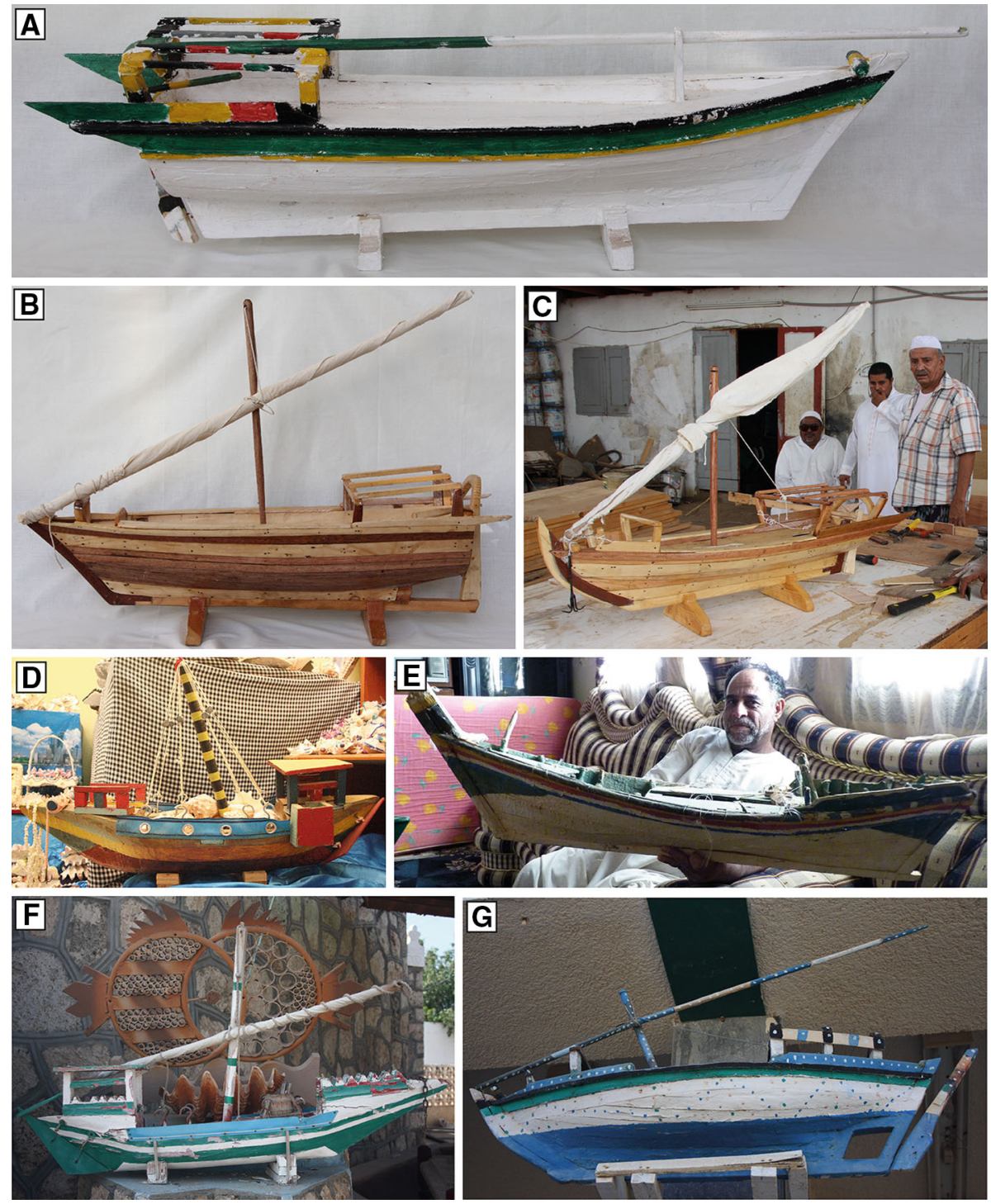

Fig. 6 a A model of a sanbūk made by Muhammad Hadrami Abdo at the boatyard of Ibrahim Bilghaith (Image: J. P. Cooper); b a model of a straight-stemmed za ìma, also by Muhammad Abdo (Image: J. P. Cooper); c a model of a curved-stemmed za īma, also by Muhammad Abdo (Image: J. P. Cooper); d a model boat, possibly referring to a an 'obrī, in the shell-ornament showroom of Mohammad Al-Zayla'i (Image: J. P. Cooper) e Ala Allah, from Muharraq, Greater Farasan, with his model of an 'obrī (Image: D. A. Agius); $\mathbf{f}$ a boat model on display in the carpark of the Farasan Governorate building, probably an 'obri (Image: J. P. Cooper); g a boat model on display above the entrance of the Farasan Governorate building, probably a za ìma (Image: J. P. Cooper)

2010: 76-77, 2014: 146-148), suggesting that the models represented a particular local tradition. Sanbük is a generic term covering double-ended and transom-ended vessels of various types, but none of those previously encountered by the authors, materially or in 

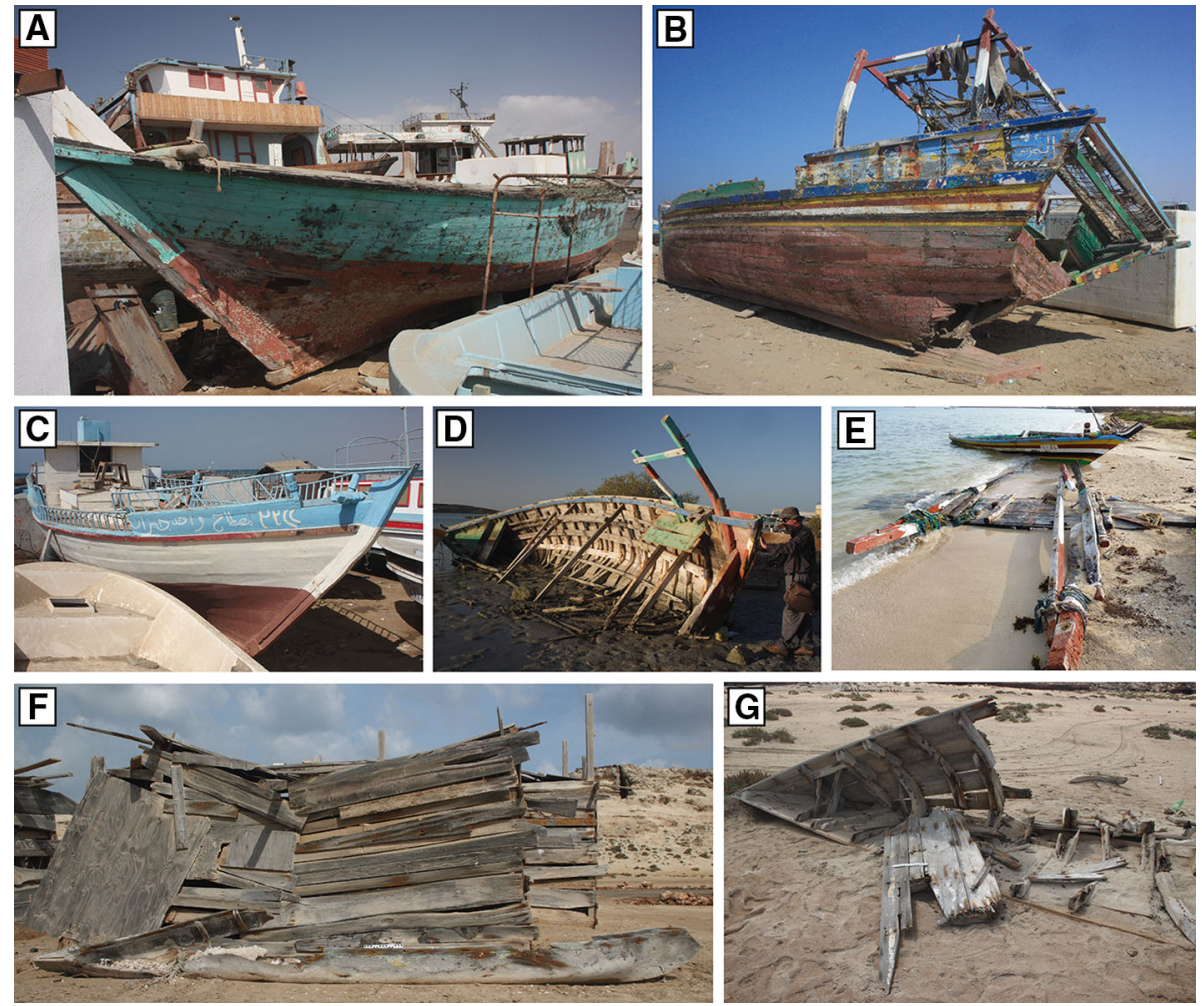

Fig. 7 a A disused wooden $s h \bar{u} '$ from the UAE of a type made in Oman and the Arabian-Persian Gulf, beside the boatyard of Ibrahim Bilghaith, Jizan (Image: J. P. Cooper); b a disused Yemeni hürī, beside the boatyard of Ibrahim Bilghaith (Image: J. P. Cooper); c A vessel described by Abdo Bilghaith as a cargocarrying $h \bar{u} r \bar{\imath}$ at the boatyard of Ibrahim Bilghaith (Image: J. P. Cooper); d an abandoned Yemeni hūri in Khor Farasan, apparently seized by the coastguard (Image: J. P. Cooper); e Fragments of ship hull, some probably Yemeni, at Khabs (Image: D. A. Agius); f a dugout $h \bar{u} r \bar{\imath}$ abandoned alongside a fisherman's shack at Sadayn, Greater Farasan (Image: J. P. Cooper); g fragments of a plank hūrī abandoned above the head of the beach at Sadayn, Greater Farasan (Image: J. P. Cooper)

texts, resemble Bilghaith's sanbūk model. In other parts of the contemporary southern Red Sea, a za ìma is a double-ended vessel characterised by "a curving bow profile" (Agius et al. 2010: 76-77). Bilghaith recalled that the largest type of vessel was an ocean-going za ima which had sailed to the Arabian-Persian Gulf, West Indian coast and East Africabut the type of za ima to which he referred was not clear.

Wooden vessels abandoned and largely forgotten on props around the perimeter of Bilghaith's yard testified in their abandoned state to the range of vessels that had been built there in the past, and of vessels from elsewhere that had ended their useful lives there (Fig. 4b, c, 7a, b). In the latter category was the hulk of a wooden $\operatorname{sh} \bar{u} \mathfrak{l}$, originating in the United Arab Emirates (Agius 2002: 89) (Fig. 7a). The distribution of barnacles on it suggested that it had spent some time holed in shallows before ending up at its current resting place. Also hauled up, and in a state of decay, was a large "winged" hüri from Yemen, the most frequent type of wooden vessel still found on that country's Tihama coast (Fig. 7b; Prados 1996a: 95-98, b: 52-56, 1997; Agius et al. 2010: 78, 2014: 147-148). Like 

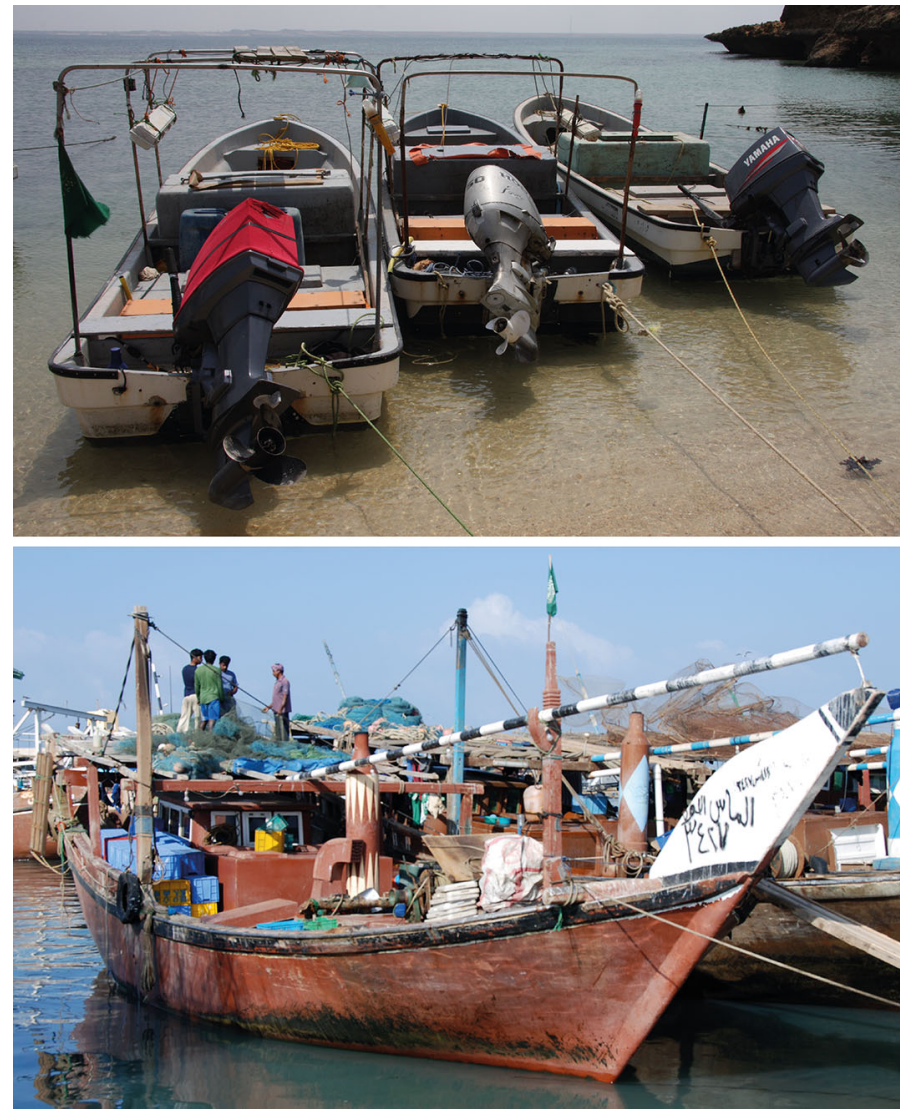

Fig. 8 Above Imported fibreglass falūkas with outboard motors at Sadayn, Greater Farasan (Image: J. P. Cooper); Below fibreglass-coated vessels modelled on the Omani and Arabian-Persian Gulf $s h \bar{u} t$ are the mainstay of the contemporary Jizan fishing fleet (Image: Peter Harrigan)

an 'obrī at the bow, this vessel has a low transom stern to accommodate an outboard motor, together with characteristic stern-quarter "fins" (Agius et al. 2010: 74-78, 2014: 147-148). In addition, Abdo Bilghaith named as a sanbūk an abandoned transom-sterned wooden vessel with a slightly convex raking prow that had been covered with a fibreglass skin to extend its life (Fig. 4b). This hull broadly resembled the sanbūk model donated by his father, although it had been adapted to take an inboard motor. Elsewhere, Abdo identified as a $h \bar{u} r \bar{\imath}$ a relatively small transom-sterned cargo vessel with a curved prow, the hull of which broadly resembled the za ima model his father had shown us (Fig. 7c). This too had been designed to take an inboard motor, and was abandoned.

The main contemporary fishing fleet of Jizan is based in a harbour adjacent to the Bilghaith yard. The vessels moored there were all fibreglass, and based in hull form on the Omani/Gulf $s h \bar{u} \mathfrak{l}$ rather than any local craft (Fig. 8). The 46-year-old Abdo Aqili, the SCTA's representative on the Farasan Islands and our guide, said that these too were known locally as 'obrīs, thereby rejecting their "original", but foreign, name, and retaining a more local one. Moreover, they were built locally, and so reflect a localisation of a popular form from eastern Arabia. 
Table 2 Names and dimensions of thehürīs in the racing fleet used during festivals in Jizan

\begin{tabular}{lllc}
\hline No. & Given name of boat (Arabic) & Translation & $\begin{array}{c}\text { Dimensions (m) (length } \times \\
\text { breadth } \times \text { depth amidships) }\end{array}$ \\
\hline 1 & al-'Umda & Support & $7.49 \times 1.7 \times 0.43$ \\
2 & al-Lihās & Short of food & $7.91 \times 1.04 \times 0.40$ \\
3 & Qāșid al-karīm & The Well Meaning & $8.08 \times 1.06 \times 0.45$ \\
4 & Amjad al-khayr & The Most-Praised of Goodness & $9.50 \times 1.20 \times 0.41$ \\
5 & Unnamed & - & $7.68 \times 1.03 \times 0.41$ \\
6 & Unnamed & - & $7.68 \times 1.02 \times 0.38$ \\
7 & al-Maḩūz & The Protected & $9.81 \times 1.24 \times 0.48$ \\
8 & Al-Jamal & The Camel & $10.22 \times 1.30 \times 0.47$ \\
9 & Zabīd & Zabid (Yemeni town) & $10.45 \times 1.28 \times 0.43$ \\
10 & Jūrī & The Damask Rose & $10.40 \times 1.29 \times ?$ \\
11 & al-Riyād & The Gardens/Riyadh & $9.55 \times 1.20 \times 0.44$ \\
12 & al-'Umda & Support & $10.37 \times 1.32 \times 0.46$ \\
13 & Al-Hijāb & The Veil & $10.77 \times 1.20 \times 0.42$ \\
14 & Unnamed & - & $8.64 \times 1.18 \times 0.43$ \\
15 & al-Ra'd & Thunder & $8.10 \times 1.06 \times 0.39$ \\
16 & Unnamed & - & $9.15 \times 1.04 \times 0.36$ \\
17 & Al-Dabāgh & The Tanner & $7.38 \times 1.07 \times 0.42$ \\
18 & Kuntum [?] & You (pl.) were [?] & $8.67 \times 1.36 \times 0.46$ \\
19 & al-Majd & Praise & $10.02 \times 1.23 \times 0.46$ \\
20 & Al-Karam & Nobility & $7.74 \times 1.12 \times 0.41$ \\
21 & Jūd 7 & Generosity 7 & $9.76 \times 1.21 \times 0.46$ \\
22 & Unnamed & - & $7.74 \times 1.12 \times 0.40$ \\
23 & Unnamed & - & $7.87 \times 1.05 \times 0.40$ \\
\hline & & &
\end{tabular}

Although the building of large wooden dhows has ended in Jizan, there still exists some contemporary building activity in the making of racing hüris - again carried out by Ibrahim Bilghaith. These, Bilghaith said, are built, maintained and raced to mark the two Muslim Eid celebrations (see below).

This fleet of racing hüris was stored on a hard close to the Bilghaith yard at al-Hafa. It comprised 23 double-ended plank vessels (Table 2). Each had a relatively straight, raking prow and stern, and a sheer line that curved slightly upwards at bow and stern (Figs. 9, 10a). The carvel planking was nailed, and the internal framing timbers followed the typical pattern of traditional vessels in the southern Red Sea in that pairs of half-frames (s. shilmān) alternated with floor timbers (s. hadrūs) that were sometimes continued by futtocks (also shilmān). The mast was stepped through a thwart.

The racing $h \bar{u} r \bar{l}$ is steered using a central rudder, mounted on the sternpost, which is controlled using two ropes running forward into the hull. Propulsion is by means of a single settee sail attached to a yard comprising a central bamboo element extended by two rough wooden rods inserted into the hollow ends of the bamboo: these are designed to fail in strong winds to prevent capsize. The yard is mounted on a mast some $2.78-2.98 \mathrm{~m}$ in height, and $8 \mathrm{~cm}$ in diameter. During sailing, a counterbalancing pole ( $m a^{\prime} \bar{a} \mathrm{~d} i l \bar{\imath}$ ), serving the function of a hiking board, is run athwart and extended outboard on the windward side. A crew-member sits on the pole as a counterbalance to the force of the wind. One other crew-member operates the rudder, and a third the sail. We were shown the 

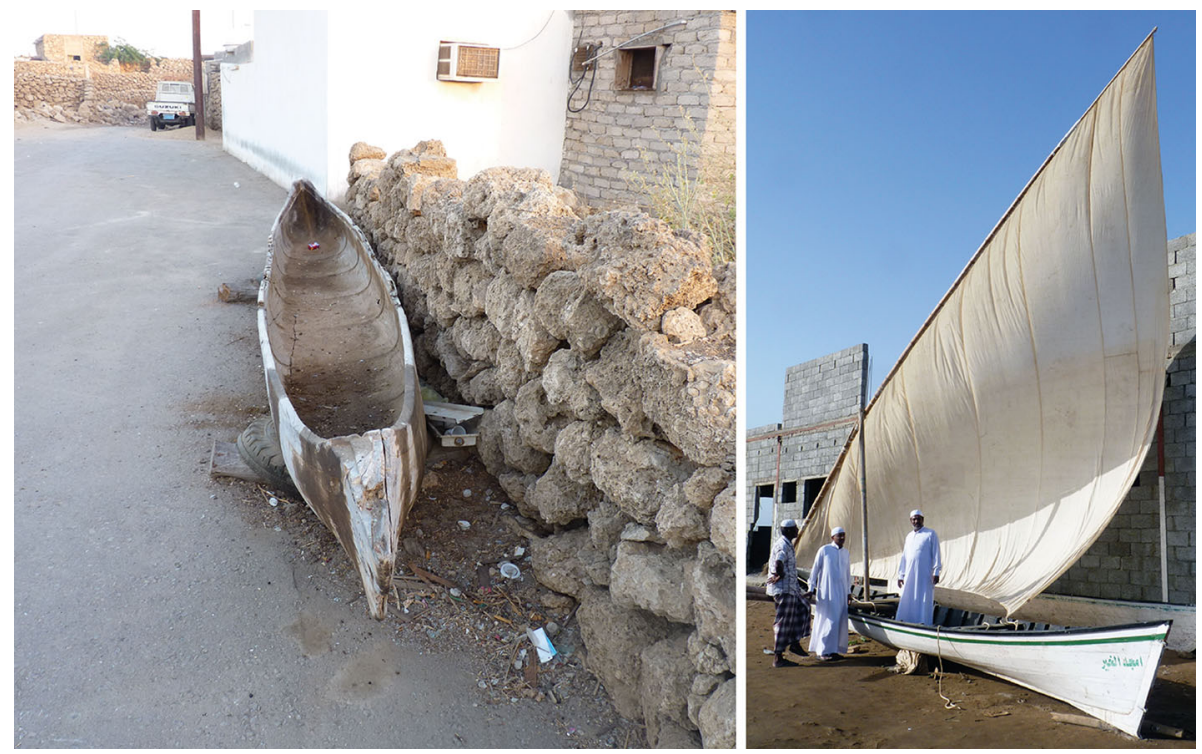

Fig. 9 Left The Aqili family's dugout hūrī in the village of Muharraq, Greater Farasan; Right a rigged racing $h \bar{u} r \bar{\imath}$, built by Ibrahim Bilghaith at al-Hafa, Jizan (Images: D. A. Agius)

counterbalancing poles, some of which were being used to hold the vessels off the ground. A plan drawing of one of these vessels, the Qâsid al-karim (The Well-Intending; vessel 3 in Table 2) is reproduced in Fig. 9. The boats are retained and maintained for the purposes of the Eid races only. Since this is virtually the only sailing the crews do today, the sailing skills demanded of them are extremely limited, comprising a linear race on a single tack towards land.

One local sailor, Ahmed Mohammed Shahhar, a 56-year-old fisherman, ${ }^{7}$ shared his knowledge on the sails: these were made in a place called Khabat from a fabric he called $h \bar{u} k$, which was imported from Aden or Bahrain. The latter had been known for sail-making in the 1940s and 1950s (Agius 2005: 53, 186). On the Farasan islands, meanwhile, informants from Qumah recalled that sails had been made from a material called mabrad. Balghaith told us that the sails were made from cotton—-formerly Egyptian, but more recently Malaysian. ${ }^{8}$

While vestigial boat building, or at least repair, continues in Jizan, it has long since ceased in the Farasan Islands. Local historian Ibrahim Muftah reported that over the past century there had been about five known dhow builders in the islands, building pearling vessels. ${ }^{9}$ The last of these, Abdo Hasan Mujawir, had died some years ago. Muftah recalled contemporaries of Mujawir, including Abu Bakr Bakhudayr, Muhammad Ahmad Khamis, Muhammad Jawhar, and Abu Muhammad Isa al-Aqili. ${ }^{10}$

In the past, small, planked fishing hüris had been constructed in Sayer village on the island of Segid, as probably they had elsewhere on the islands. We interviewed

\footnotetext{
7 Interviewed on 11 and 12 May 2010.

8 Interviewed on 11 January 2010.

9 Interviewed on 13 January 2010.

10 Ala Allah Abdo Hasan Mujawir, Interviewed on 15 May.
} 

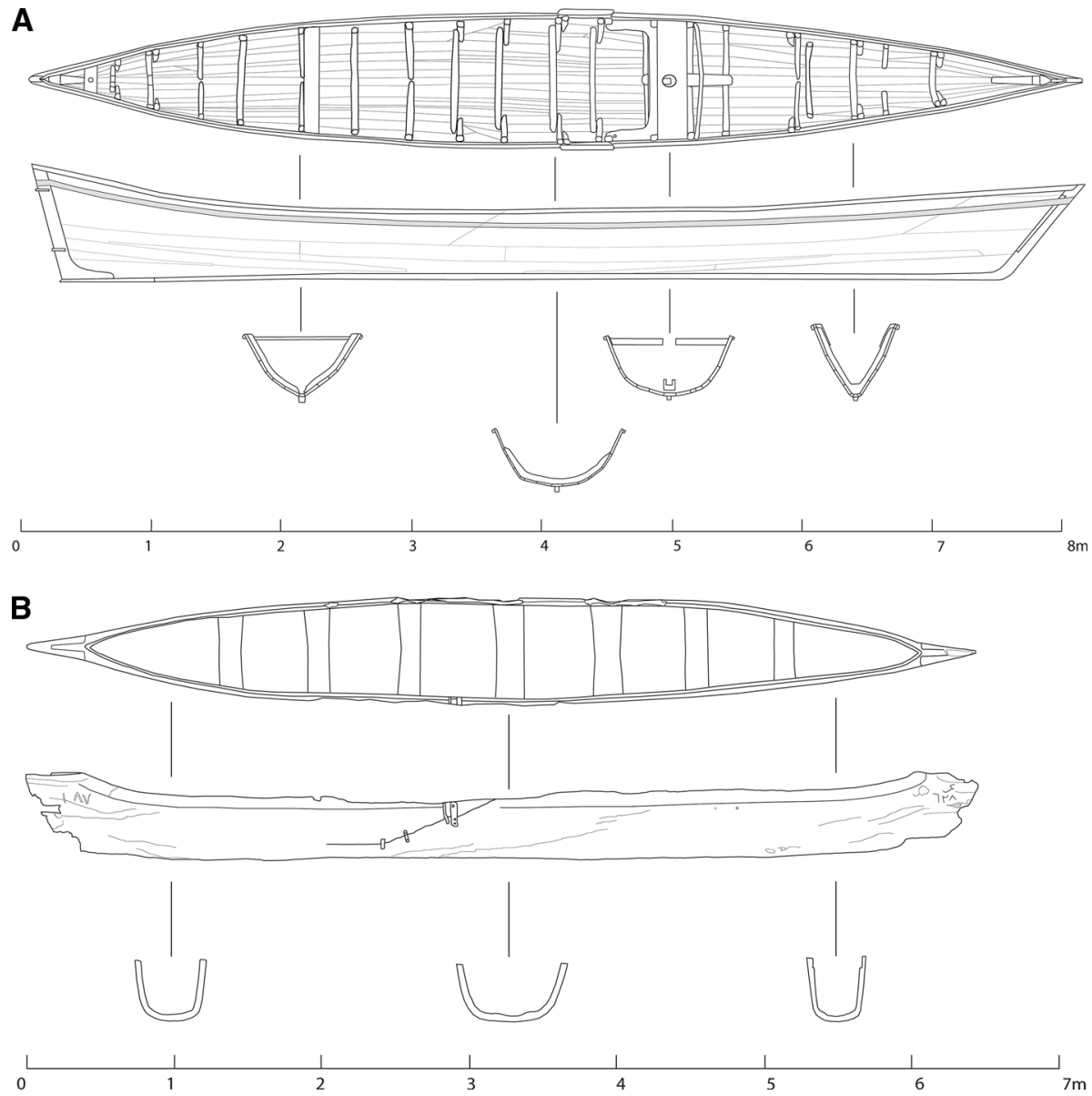

Fig. 10 a Plan drawing of the Qāṣid al-Karìm, a racing hūrī, recorded at al-Hafa (Image: L. Semaan \& C. Zazzaro); b Plan drawing of the Aqili family's dugout hūrī, recorded at Muharraq (Image: L. Semaan \& C. Zazzaro)

Muhammad Uthman Mahmud Hanas, in his $70 \mathrm{~s}$, a former pearl diver who had turned to fishing later in his life. ${ }^{11}$ He recalled that his uncle had been a boat builder, making plankbuilt hüriss for pearling and fishing in a small workshop adjacent to his house. The boats were some 20 dhiră' (cubits) long (about $8 \mathrm{~m}$ ), carried six persons, and were propelled either by oars (Far. sayb, pl, suyūb) or a sail, he recalled. The framing timber was locally sourced mangrove (see below), and the planking brought from Jizan. Local blacksmiths manufactured the nails, as well as the gudgeons and pintles for rudders, Muhammad recalled. Nothing remains of the workshop today. "We were young boys," recalled Muhammad. "Six of us would carry the finished hürī on our heads and walk from the village to the coast" - a distance of some $1.3 \mathrm{~km}$.

11 Interviewed on 24 May 2010. 


\section{Timber}

The building of wooden boats may have largely ceased in Jizan and the Farasan Islands, but those physical vestiges that remain, in passive remembrance of former activity, enable reconstruction of something of the array of timbers formerly used in local construction, in addition to the recollections of craftsmen. ${ }^{12}$ The authors collected some 28 wood samples during the two field seasons for species identification. This allowed a comparison with the recollections of informants where these were expressed: otherwise, sampling was the sole source of information on timber types where no interviewees were available.

In phytogeographical terms, Jizan province is part of the South Hejaz region, which stretches from Jeddah to Yemen (Migahid and Hammouda 1974: 6). Due to its relatively high rainfall, it is home to three quarters of Saudi Arabia's plant species, including some 70 tree species (Al-Nafie 2008: 161, 169). The most common trees are Acacia spp. Mill., juniper (Juniperus spp. L.), olive (Olea europaea L.), and Christ's thorn jujube (sidr or 'urj; Ziziphus spina-christi (L.) Desf.; Fig. 3b) (Migahid and Hammouda 1974: 468, 456, 446). Other species observed during the fieldwork included the doum palm, barzūma and neem (Fig. 3a, c, d). ${ }^{13}$ However, these timbers exist in relatively limited quantities, and their frequently crooked nature restricted their use in boat-building, especially with respect to planking. Shipwrights recalled the historic need to import wood from overseas. Again, our most important informant was Ibrahim Bilghaith, who recounted the types of wood used in shipbuilding, their local names and names used elsewhere, their countries of origin, and points of import into Saudi Arabia. He recalled that a number of species had been imported from India and other Asian sources in the past, the most prized being Indian teak (sāg; Tectona grandis L.f.). He also allowed us to take samples from natural crooks, and derelict boat parts.

Using his model za ìma in demonstration (Fig. 6c), Bilghaith recalled the local names of types of wood that had been used in boat building, together with their origins. In the past, keels, stem posts and hull planking had been made of teak: "It is a very robust and, durable wood, and suitable for building large vessels; planks of 12-14 $\mathrm{m}$ in length can be obtained." Teak had been imported via Jeddah, he said, but today only recycled timbers were available, because imports ceased around 25-30 years ago following Indian export bans. Today, teak "is as valuable as gold, and very expensive-12,000 or 14,000 Saudi riyals $/ \mathrm{m}^{3}$." Bilghaith retained a relic of the teak trade at his yard, in the form of a disarticulated teak keel, lying on blocks among the yard's abandoned vessels; it had been reused "up to thirteen times", he said (Fig. 11c). Made from a single log and rabbeted to accommodate garboard strakes, the keel measured $1370 \times 28 \times 22 \mathrm{~cm}$.

Masts and yards on larger vessels were in the past typically made of mantīk, which Bilghaith recalled had been imported from India via Dubai. ${ }^{14}$ "As it is as strong as teak it might also sometimes be used for the keel", he said. Two samples taken from used mantīk planks at the yard were identified as Hopea sp. Roxb. ${ }^{15}$ - a genus comprising over 104 species and distributed from India to New Guinea (Mabberley 2008: 412): it is closely related to, and sometimes included in, the genus Shorea sp. Roxb. Ex C.F. Gaertin, itself a

\footnotetext{
12 For a full discussion of timber types used in Red Sea boatbuilding, see Semaan (2015).

13 Abdo Mohammad Isa Aqili interviewed on Greater Farasan on 14 May 2010 pointed out an invasive species of what appeared to be of Acacia which he called shajarat al-amīr, 'the Emir's tree'.

14 Mantīk is sometimes referred to as benteak, for example in the Gulf (Agius 2005: 31). Phonetically/b/and/ $\mathrm{m} /$ are bilabial and interchangeable.

15 Gerisch, personal communication, 8 January 2012.
} 

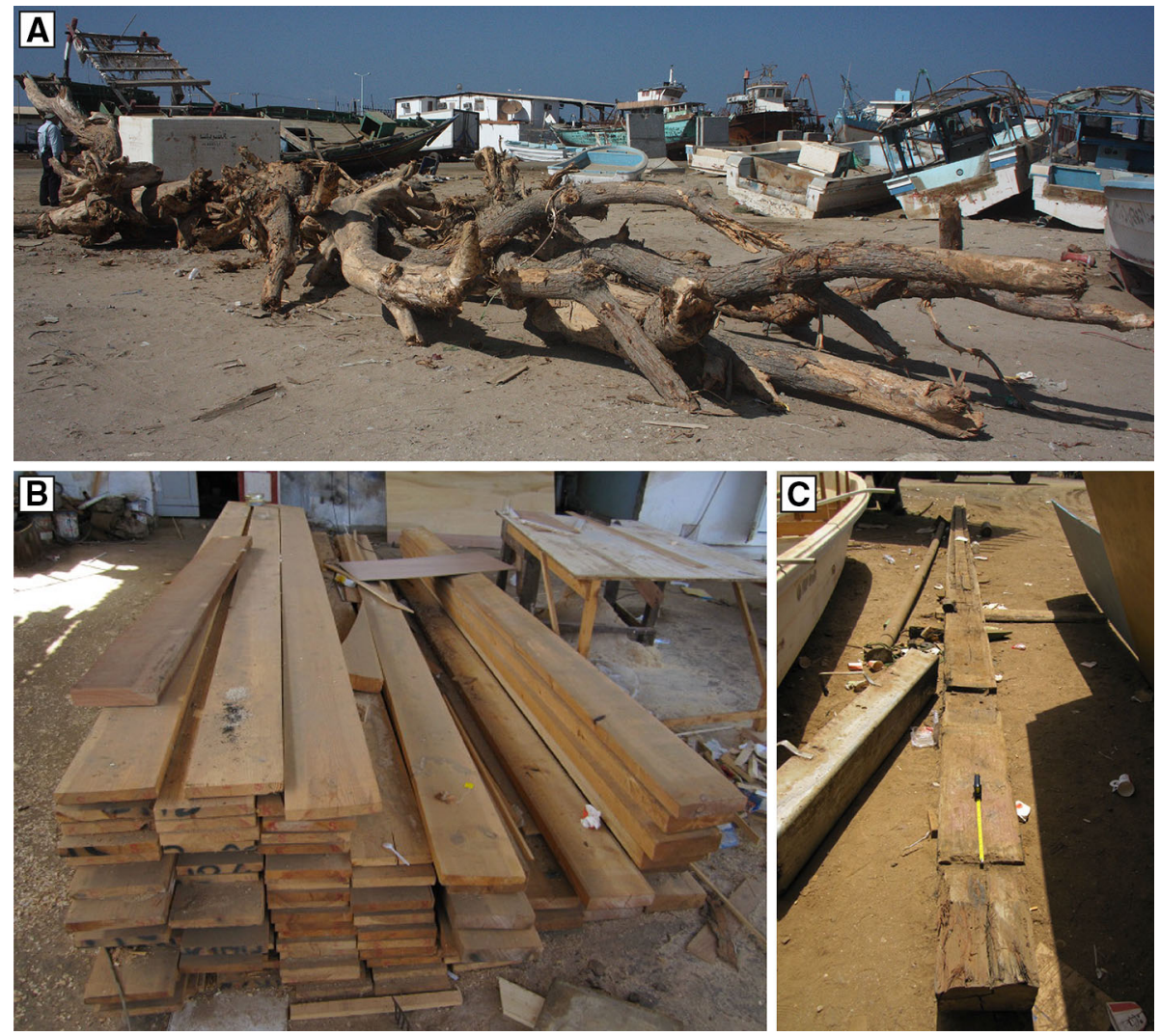

Fig. 11 Timbers at the yard of Ibrahim Bilghaith, al-Hafa, Jizan: a Unworked neem crooks (Image: J. P. Cooper); b Imported pre-cut planks of Swaydi' ('Swedish') timber, identified from samples as pine (Pinus spp) (Image: L. Semaan); c Disarticulated keel made of teak at the Bilghaith yard, al-Hafa, Jizan (Image: L. Semaan)

genus of around 196 species distributed in tropical and south east Asia (Mabberley 2008: 794).

The end of Indian timber exports prompted a reconfiguration in timber use in boat construction, and relics of this subsequent period were also distributed around the yard. These occurred in three forms: as natural logs of locally grown timber; as imported, readysawn planks; and as recycled components, such as the teak keel (Fig. 11a-c). Given that the only work in wood that the yard currently conducted was the repair of a dwindling fleet of wooden boats, the rate of consumption had diminished radically. Vestigial piles of crooks around the yard were largely locally grown neem, which once provided crooks for knees and framing timbers. "Boat-builders prefer to get wood in that form since they have more freedom to control the shapes", Bilghaith said: individual timbers were selected according to the required scale and shape. Outer and inner stem posts was often also made of neem, he said. Framing timbers might also be made from Christ's thorn jujube, since both were considered strong woods that are easy to work. The latter was also used for beams and stanchions: Bilghaith said that it could be sourced locally in Jizan and nearby Sabya. When Egyptian boat designs and with them Egyptian carpenters came to the yard, 
he said that he had also used imported Egyptian mulberry (tüt; Morus spp. L.) for the framing timbers of those vessels. ${ }^{16}$

The loss of teak supplies had also forced builders to turn elsewhere for durable planking. Bilghaith recounted that for hull timbers he had in recent years typically used "Javan" (jāwi) timber, which he also called "red wood" (khashab ahmar). One plank of this was sampled and identified as Shorea spp. The timber was bought from suppliers in Jeddah, such as the Bashikh and Fawzan companies, he said. A further tropical wood, which Bilghaith identified as meranti (marantī; again identified through sampling as Shorea spp.) was typically used in the awning superstructure, though he identified it as "as valuable as teak". He believed it to be "imported from Kenya", although it originates in east and south east Asia (Gottwald 1968: 36; Durand 1986; Mabberley 2008: 539): the discrepancy speaks of the detachment of the builder from the international timber market.

Bilghaith referred to a quantity of pre-sawn pine planking around the yard as "Swedish" $($ sweydī) and "Romanian" (romāni $)$ wood (Fig. 11b). Samples of these proved to be pine (Pinus spp), ${ }^{17}$ a timber that was used in large quantities in the upper hull planking and superstructure. At the time of our visit, however, it was used at the yard in place of all the other woods in the repair also of lower hull planking, for example on an Egyptian-style fishing vessel (Fig. 5). Bilghaith said that "Romanian" timber was sometimes used for decking, but was rarer and more expensive.

Stacks of bamboo (bashkìr; Bambusa spp. Schreb.) at al-Hafa were still used as yards for racing hüriss, being strong, light, and cheap. Bilghaith believed it had come from Egypt, Kenya and India, although only the latter is likely.

Given the absence of shipbuilding activity on the contemporary Farasan Islands, recollections of the use of wood in shipbuilding were sporadic. Muhammad Hanas from Sayer recalled that his uncle built his hüris from of a type of wood he called shām, identified from a sample as Pinus sp. ${ }^{18}$ The framing timbers were made from either red or white mangrove (gandal or shüra), which were brought from the islands of Zafaf (زفاف) and Kira (كيرة) (Fig. 1). In adult life, Hanas recalled crewing on long voyages aboard sanbūks which, he said, had been made using "red Javan" wood (jāwi aḥmar).

Bilghaith recalled the measures that were taken in the past to protect wooden vessels from shipworm damage. He said that dhows were careened roughly every 6 months: traditionally, nüra (lime powder) mixed with animal lard to form shahm, a mixture that was applied to those parts of the hull lying below the water line. Interior timbers were smeared with sîf $a$, a compound based on shark-liver oil; today, petrochemical paints are used, and the traditional techniques are being set aside.

Both Ibrahim Bilghaith and Ibrahim Muftah recalled that dugout hüris were made of 'anba, a word for mango (Mangifera indica L.) that is also used in Yemen (Al-Hubaishi and Müller-Hohenstein 1984: 199; Wood 1997: 200; Provençal 2010: 22; Semaan 2015: 305). Their identification was confirmed through testing of a sample from the hūri at Sadayn (Fig. 7f). ${ }^{19}$ Hürīs were made on the Malabar coast of India, and shipped on board larger vessels throughout Arabia.

\footnotetext{
16 Interview of 10 January 2010.

17 "Pinus spp., with window-like cross-field pits". Gerisch personal communication, 8 January 2012.

18 “Pinus sp., with pinoid cross-field pits". Gerisch personal communication, 8 January 2012.

19 All scientific identifications of wood timbers collected during the fieldwork are by Rainer Gerisch (gerisch1@aol.com).
} 


\section{Remembering Boats}

\section{Forgetting Boats: Material Remains}

"When thinking about memory," writes Assmann (2010: 97), "we must start with forgetting." With respect first to the physical traces of traditional watercraft of the Farasan Islands and of Jizan beyond Bilghaith's yard, there has been far more active and passive forgetting, in Assmann's terms, than there has been remembering. Overwhelmingly, the working fleets of trading, fishing and pearling vessels of the twentieth century no longer exist, and almost no exemplars survive physically. Following abandonment, larger vessels were mostly left to decay or be gradually dismantled in the shallows, until no visible trace remained, while smaller craft were often broken up or simply hauled to the beach head, and abandoned to the elements (Fig. 7a-g).

Hence, boats are usually not among the material culture finding its way into an inventory of materialised memory. Of the few vessels that had survived enough of the process of active forgetting that enabled us still to encounter them, most were in a state of advanced deterioration. In the cove at Șadayn (صدين) we encountered the disintegrating remnants of four plankbuilt vessels: one was by the shoreline, the others being subsumed beneath aeolian sand above the head of the beach (Fig. $7 \mathrm{~g}$ ). One of these had been bulldozed through during improvements to the road serving the beach. The 4-m-long remnant of a dugout hüri lay alongside one of the fishermen's shacks, badly damaged and part-filled with dead coral (Fig. 7f). New fibreglass fishing vessels were moored in the shallows, successors to these wooden hulks. Local fishermen call these falüka (Fig. 8). Elsewhere on the island, large, plank-built fishing hürīs from Yemen rotted away in the Khor Farasan creek (Fig. 7d, e). The Saudi coastguard had seized these from their Yemeni crews for allegedly fishing illegally in Saudi waters, and subsequently abandoned them. The authors found remnants of two other large hulls disintegrating in the water at Tibtah (تبنة; Fig. 7e). Two other abandoned dugout hürīs were found: one, fairly intact, on Qumah, and a fragment of one on the rocky shore west of Khutub. Elsewhere, individual ship's timbers had survived through their incorporation into pre-oil-era buildings (Fig. 12c-d), often as lintels, making them a repository of information on shipbuilding practices.

\section{Recalling Boats}

Beyond the material remains of vessels encountered, oral testimony vouched for a broader range of boat type and use than present remains suggested. However, terminology and context constitute significant barriers to the safe association of boat type-names and descriptions recalled by interviewees with past material forms. Vessels in the region are normally named with respect to their hull shape (Agius 2002: 31-114, 2005: 13-24; Moore 1970 (1925): 120-126; Hornell 1942: 15-36). However, more than one hull form may take the same name-for example sanbük and hüri-even within the same location, and certainly across space and time. Ibrahim Bilghaith recalled to us a vessel he called a za ìma (pl. za' âyim), the largest in the region, which sailed to the Arabian-Persian Gulf, India and East Africa. Its convex upper stem-post is reminiscent of the za'imas found very rarely in Yemen today (Agius et al. 2010: 77). Informants in the islands, particularly in the village of Khutub, recalled a vessel type called $s^{c} i y a$ (pl. sawa' $\bar{\imath}$ ), but no one could describe it other than to say it somewhat resembled a sanbūk. Meanwhile Ibrahim Muftah recalled two other types - a double ended būt (elsewhere bōt; pl. abwāt), and a qatīra, resembling a za'ima, and built locally. But we had no means of establishing the form of these vessels. 

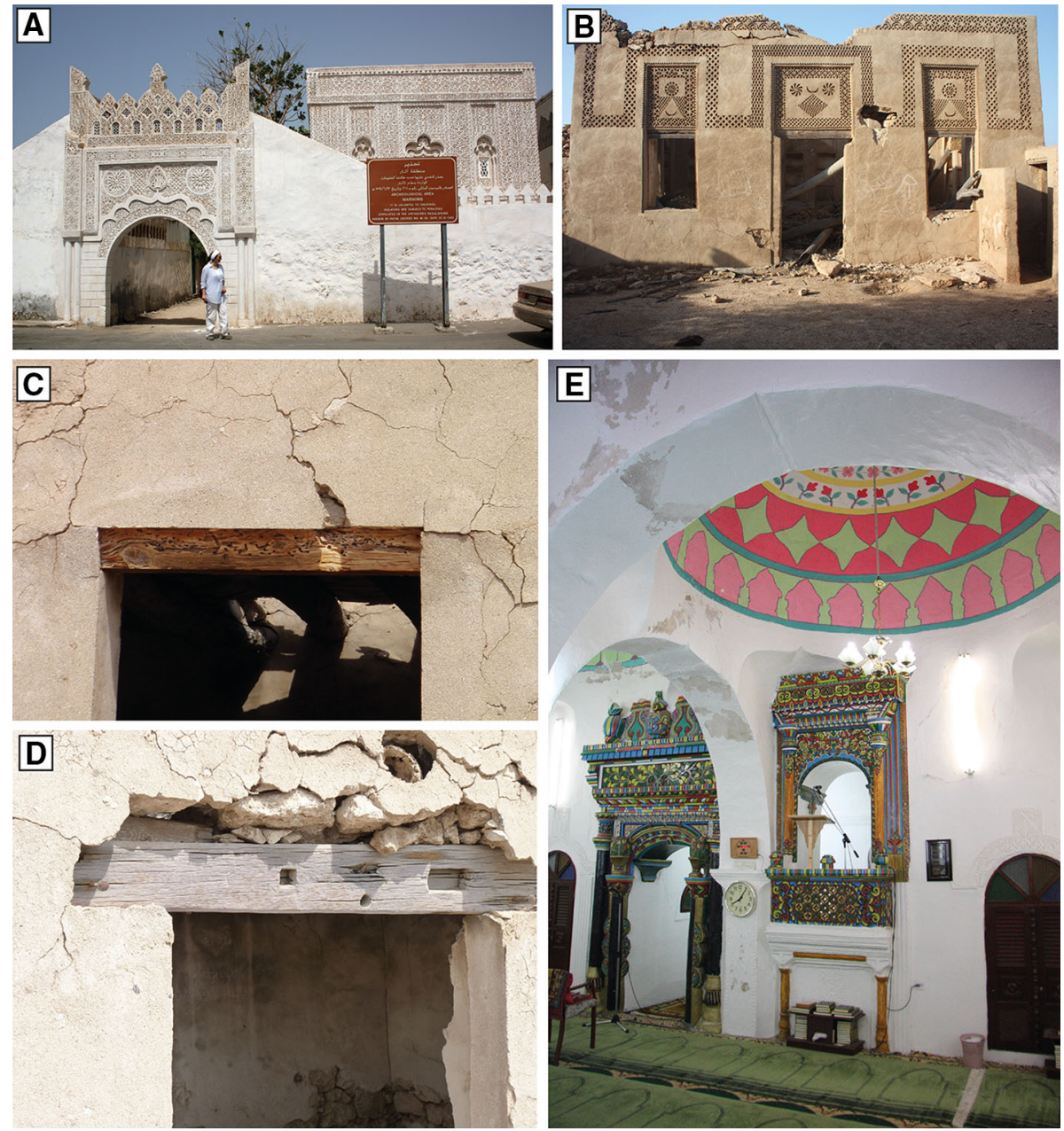

Fig. 12 Active remembering and passive forgetting of the built heritage: a The former house of pearling merchant Munawwar al-Rifa i, restored by the SCTA (Image: C. Zazzaro); b an abandoned house showing typical stucco decoration in al-Qusar village, Greater Farasan (Image: J. P. Cooper); c a ship's timber bearing shipworm borings, re-used as a lintel in an abandoned house in Sayer village, Segid (Image: C. Zazzaro). d a timber re-used as a lintel in an abandoned house in Khutub, Segid island (Image: J. P. Cooper). e interior of the Ibrahim al-Najdi mosque in Farasan town, built in 1347/1928 by a pearl merchant. The brightly painted surrounds of the prayer niche (mihrāb) and pulpit (minbar) were brought from India (Image: J. P. Cooper)

\section{Remembering Trading and Pearling Vessels}

Despite the limitations of understanding the materiality of past vessel types through verbal recollection only, several individuals reminisced about vessels they had encountered and experienced.

The trading ocean-going vessels (marākib lis-safar) were known as sanbūks or za'ìmas; they had, as Ibrahim Bilghaith recalled, a capacity of 500-1000 date sacks (s. kis; pl. 
akyās), each of which weighed 9 farāsila. This convention of using date, sugar or rice sack units to express capacity is widespread in the region. Several skippers recalled that the sanbüks sailed in convoy (sinjār), stopping at anchorages in the southern Red Sea. Waiting for the shamāl (northerly) wind, which coincided with the southwest monsoon, they departed around July, stopping in Aden, then one or two other ports on the southern Arabian coast, as well as Sur in Oman. Some ventured to the south coast of India before sailing on to join others at Basra for the September date harvest, where they would take on sacks of dates. They would set off in October for their return journey with the $a z y a b$ winds, also known as the janūb ("southerly"), in other words, the northeast monsoon winds.

The round trip, we were told, lasted about 6 months, during which the cargo ships stopped at various ports to sell the cargo and negotiate with traders to take on board new cargoes before setting sail again. Jizan was, until 50-60 years ago, a transit port that received frankincense from Dhofar and Hadhramaut; from India via Aden, according to Ibrahim Bilghaith and Ibrahim Muftah, ${ }^{20}$ came traditional Indian clothes and footwear, and also food, such as sugar, rice, flour, cooking butter, oil, and sweets such as honey and hulqüm, sugar, mastic and pistachios. Meanwhile Jizan exported cereals, barley, and raisins to other Red Sea locations. Imports from Massawa, Eritrea, to Farasan Islands included tobacco, oil, rice, flour and cooking utensils, and from Somalia camels, sheep and goats.

Sheikh Yahya Ibrahim Al Najdi Al Tamimi, from Farasan town, then in his $70 \mathrm{~s}$ (Fig. 1d), was proud to recall that when he served as a sea captain he had owned a sanbük that was a remarkable $35 \mathrm{~m}$ long and $8 \mathrm{~m}$ at the beam, and had been built in the Yemeni Red Sea port of Luheyya: "The finest $s a n b \bar{u} k$ s were built in Yemen at Luheyya and Hodeidah," he said. His sanbūk was equipped with an inboard engine and a mast and sail; the latter was used in fair winds or if the engine failed. The vessel, he remembered, had lasted for 25 years before it was damaged and finally abandoned at the anchorage at Tibta.

Owning a sanbük was prestigious in the marine business hierarchy. Ibrahim Muftah recalled to us that his father had owned one. One informant, a pearl diver, Mohammed Abdalla Ahmed Nasib, 74, recalled that he had worked for a man called Hadi Bin Hasan, who had owned five.

While local individuals have managed to retain smaller, low maintenance and often cheaper material items of the maritime past, such as pearling paraphernalia, watercraft had, as we have seen, largely been left to decay and disintegrate: thus, while smaller items such as pearling baskets, knives and chests found their way into the community repertoire of tangible memory, boats, because of their size, residual value and cost of maintenance, largely have not.

There was at least one exception to this situation. In the village of Muharraq, on Greater Farsan, the Aqili family kept their 6.4 m-long dugout hüri on the roadside close to their home as a family souvenir, albeit one receiving little or no active maintenance (Figs. 9, 10b). The boat belonged to Muhammad Isa Ahmed Aqili, who was over 100 years old, and not available to talk to us. The characteristic features of the hull pointed to an origin on the Indian Malabar coast, whence hüriss originated (Blue et al., forthcoming; Jansen van Rensburg 2010: 103; Agius 2002: 119-121; Hornell 1942: 30). These included seven carved "false frames"; a carved "replica sheer strake"; and trapezoidal joints at the stem and stern heads which would originally have accommodated separate wooden bow and stern-pieces that are rarely retained in Arabia (Fig. 10b). Standing around the boat, we spoke to his sons about their father's occupation and about the hürī: The sons were Abdo, the SCTA representative and a fisherman and occasional pearl diver; his brother Isa, 21;

${ }^{20}$ Interviewed on 10 and 11 January 2010. 
and another brother, Abkar. ${ }^{21}$ The brothers said their father had been a trader, but for some 50 years he had also dived for pearls, and for șadaf for nacre (mother of pearl) on the islands of Dumsuk (دمسك) and Qumah and in Khor Farasan. Abkar shared the family narrative that his father had bought the hürì in Jeddah and had sailed it the $600 \mathrm{~km}$ or more home to Greater Farasan. He had used it to dive for șadaf around Dumsuk island, but Abkar said he had also occasionally sailed it on a settee rig with a companion for $230 \mathrm{~km}$ across the open Red Sea to Dahlak and Massawa, where he bought tobacco (tumbuk): his father had recounted to him the journey, which took about a week in fair winds or longer if contrary winds required them to resort to tacking (mujāwasha). He also sailed down the coast to Hodeidah, where he sold pearls. All that remained of the vessel on our visit was the original dugout hull, without the extension strakes that are common Arabian adaptations of the vessel for sailing in the open sea. Likewise there was no surviving rigging or steering equipment. Another sailor, Mohammad Abdalla Mohammad Abbas, a shell collector in his $70 \mathrm{~s}$ from Qumah Island, remembered that he sailed with a companion to Yemen on a dugout $h \bar{u} r \bar{\imath}$ for trade: the journey lasted 3 days in favourable winds. He could not recall to where in Yemen they had sailed, but he did say that in good winds they could sail to Jizan in a day. $^{22}$

The survival of the Aqili family's hürī beyond its working life was aided by the robust nature of its monoxylic hull, which nevertheless had many fissures: a large crack on one side had been repaired partly using small metal staples, and elsewhere by strips of metal nailed to the hull. Both ends had suffered damage, as well as part of the sheer line. It remained vulnerable in its location by the side of the road. ${ }^{23}$

\section{Boat Models}

In addition to the three boat models in Ibrahim Balghaith's boatyard in Jizan, we also encountered others that sought to recall the seafaring past of the region in a way that fullsized vessels had not been preserved to do: others, situated in official, state-owned contexts, are discussed below. One man, the 65-year-old Mohammad Al-Zayla i, made boat models and other ornaments from marine shells for sale, enabling buyers to recall the islands' maritime past in their domestic decor. Among them was a relatively simple rendition in wood of a double-ended sanbu $k$, with a single mast, and a prominent $z \bar{u} l \bar{\imath}$ (outboard toilet) recalling living conditions of the past (Fig. 6d). In Muharraq, a 45-yearold former civil servant Ala Allah Mujawir built boat models as a pastime (Fig. 6e). He proudly showed us a large, double-ended sanbūk model he had made, based on memories of his childhood, when he watched his boat builder father, Abdo Hasan Mujawir, at work: Ala recalled that his father, who had died aged 45, was the last builder active on the islands.

\section{Remembering Trade and Contact}

A further category of retained items served to recall the maritime past of the Farasan Islands. While not directly maritime in their nature, their owner remembered through them the maritime activity that had brought them to the islands. The historian Ibrahim Muftah

\footnotetext{
21 Interviewed on 11 January 2010.

22 Interviewed 23 May 2010.

23 The boat has, since our fieldwork, been struck by a vehicle and damaged (Solène Marion de Procé, pers. comm. 24 Oct 2015).
} 
retained a collection of clothing at his home, hanging on his living room walls, that he recounted was of Indian origin, and invoked for him the close connections between the islands and India in the past. Farasani pearl traders travelled via Aden to India and sometimes Bahrain, where they sold their pearls: they returned with Indian goods, largely from southwestern India. Muftah showed us a fōta (sarong), kurta (shift), țās (gold dress), khadd al-malīha (green silk dress fabric), sidayriya (cropped blouse), headscarves (asba; fal; milāya hind $\bar{\imath}$ ) and sandals (madās), all from India. Many had embroidery added in the Farasan Islands-including work in gold wire that had also been brought from India. He also showed us an Indian trunk made of saysam wood in which a bridal trousseau would have been transported. "People saw eastern designs, and brought them to their homes", he said. ${ }^{24}$ This extended to architecture: he showed us Japanese tiles found in the local mosque that he said were from the 1920s.

\section{Remembering Shipboard Society}

A number of informants recalled social structures on ocean-going merchant ships and pearling vessels. ${ }^{25}$ In both cases, crew arrangement was highly hierarchical, with men divided into a number of ranks: the sea captain (s. nākhōda; pl. nawākhida) was responsible for managing the vessel, the rigging, the ship's course, and the crew; he rationed water and enforced discipline. The navigator $\left(r u b b \bar{a} n^{26}\right)$ was familiar with coastline, currents, and winds, and steered the vessel. A compass (dīra or būssola) was often on board, but usually the navigator used the stars on moonless nights, or otherwise relied on landmarks (ishārāt). In the absence of a $n \bar{a} k h \bar{o} d a$, a boatswain (mugaddam) took charge of the vessel. Regular sailors (bahriyya) were assigned a number of jobs on board: they helped with the rigging, and raised and lowered the sails. They were also assigned tasks such as water distribution, preparing food and washing clothes: the bread-maker (tahhān), ground grain to make bread; the cook (tabbākh) was in charge of cooking; one or more cabin boys (s. walad), were assigned to make coffee and assist the cook. On pearling sanbüks, the divers (s. ghawwāṣ; pl. ghawwāșīn) and haulers (s. barrāḥ; pl. barrāhīin; v.t. yibrahūu) doubled as sailors. The youngest crew were typically 13 years old, Ibrahim Muftah recalled, though boys of seven were in addition trained as cabin boys.

Informants recalled that meals were served on board three times a day, but they differed in their recollections of what was eaten or drunk. The first meal was a very light breakfast called lubba, eaten after the dawn ( fajr) prayers, consisting of coffee and dates. The coffee was either from beans (bunn) or coffee husks (qishr). The second meal, called futūur, came a few hours later, and comprised bread, eggs, sorghum, or cereals and tea with milk, although one or two informants recalled that tea was not available. The third, 'asha, or supper, was a substantial meal with soup: fish, turtle, oyster flesh and bread. Rice was hardly mentioned as an on-board food, possibly because of the amount of water required to cook it, although it was imported to Farasan from Eritrea. The crew ate the oyster meat and flavoured it with cumin, pepper, oil, and spicy shatta mixed with sorghum for their evening

\footnotetext{
24 Interviewed 13 January 2010.

25 Information on crew was gathered by Ibrahim Ahmed Bilghaith on 10 January, 1 and 12 May 2010; Ibrahim Mousa Ahmed, pearl diver from Jizan town on 12 May 2010; Sheikh Muhammad Isa Muhammad Aqili, from Farasan, 76, on 18 May 2010; Mohammad Abdalla Mohammad Abbas and Aqil Isa Hamadi Mohammad, both in their 70 s, pearl divers from Qumah on 23 May 2010; Sheikh Yahya Ibrahim Bin Ibrahim al-Najdi al-Tamimi, from Farasan, a pearl diver and owner of a sanbūq on 24 May 2010.

26 This is a very old term going back to antiquity (i.e. Akkadian, Aramaic, Southern Arabic etc.) and used during the classical and medieval Islamic period (Agius 2005:131-132).
} 

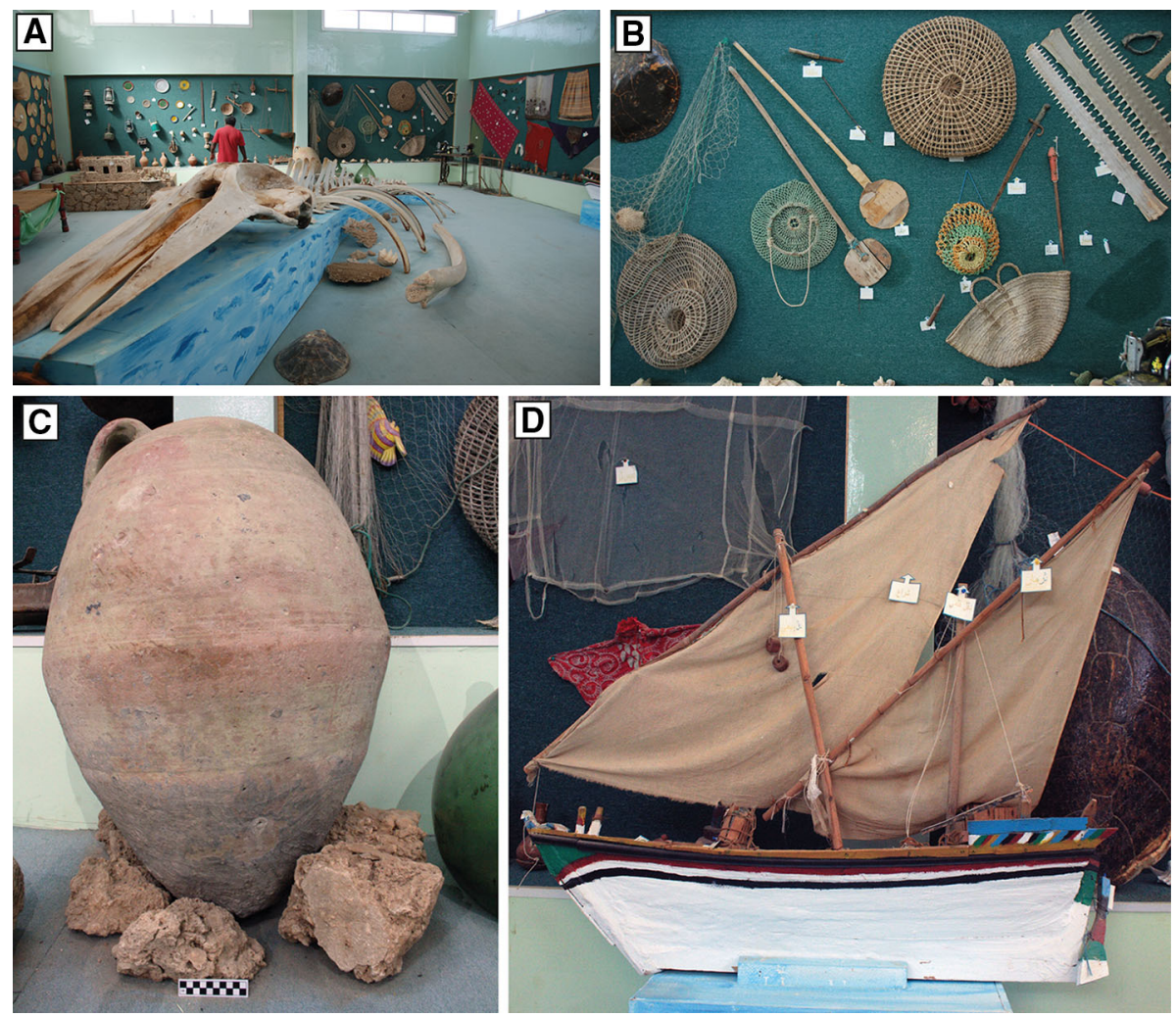

Fig. 13 a The museum of the boys' primary school, Farasan town, dominated by a whale skeleton (Image: Peter Harrigan); b Maritime artefacts on display include two oars; two rope pearling baskets (s. dangīl); a pearling knife (maflaka or maflāk); and a marine fish-trap (sakhwa) (Image: Peter Harrigan); c A $m \bar{a} ' \bar{u} n$ amphora used for storing water on board (Image: J. P. Cooper); d A model of a transom-sterned sanbük complete with rigging and labels (Image: J. P. Cooper)

meal. A delicacy was the khabat, a "finger-nail shape", we are told; it is extracted from pearl oyster (Pinctada radiata ${ }^{27}$ ) or other shells, and was pounded and mixed with dates. All food was cooked in an earthenware oven, tannür or a kānūn, in which the crew kept coal burning for coffee. The traditional way of making bread was in the mif $f$, a tall clay cylinder clad with palm branches.

Water was rationed to four or five cups (s. mughrāf) a day, recalled Muhammad Uthman Hanas, a pearl diver from Saer in his $70 \mathrm{~s}$; it was stored in a glass demijohn (dabajāna) imported from India, or a type of amphora called a $m \bar{a}{ }^{\prime} \bar{u} n$; one $m \bar{a} ' \bar{u} n$ carried 121 , we were told, although examples shown to us were clearly larger (Fig. 13c).

\footnotetext{
27 It is curious that our informants did not make specific reference to the black-lipped pearl oyster Pinctada margaritifera L. (Sharabati 1984: Pl. 41), which produced fine pearls (Sharabati 1981: 51) and ample nacre. Samples collected for the authors during dives were Pinctada radiata Leach (Sharabati 1984: Pl. 40). Not surprisingly, middens also appeared to contain only P. radiate: if $P$. margaritifera was collected, it would have been exported for its nacre.
} 


\section{Remembering Poetry and Songs of the Sea}

A long tradition on the Hijaz and Tihama coasts is the reciting of sea poetry and the singing of maritime work songs (s. nabya; pl. nabyāt) with themes such as pulling boats onshore, launching them, hoisting sails, rowing, opening shells, and the return from long voyages. Others covered subjects celebrating newlywed couples, festive occasions, and eulogies for princes and the king.

There is also a long past tradition of seafarers reciting rajaz (verse in a particular poetical metre) containing nautical directions, a tradition that goes back to the time of Ibn Mājid (d. 908/1498), for example in his Hāwiyya and Sofaliyya and earlier Persian and Arabic poems, now lost (Tibbetts 1981: 4-6). One old pearl diver and an experienced seafarer whom we met at Muharraq, Ali Khalifa Ali Hammed Damri, in his 90 s, recited verses of poetry when asked simply to talk about sailing to the Dahlak Islands: it was through verse that he retained this information, and it was likewise through verse that he was able to share and reproduce it.

We interviewed three pearl divers who sang work songs: Ibrahim Mousa Ahmed in his $60 \mathrm{~s}$, from Jizan, formerly a pearl diver and shell collector for many years. At the time of the survey, he sold fish in the souq and sang sea poetry that he and others composed, a few of which he sang for the present authors. The melody of these is not confined in its use to maritime subjects, being used in poetry of, for example, love and marriage, and eulogies, as is also the case further north in Yanbu al-Bahr and El Wejh in the Hijaz (Agius, forthcoming). Abdallah Ibrahim Hasan, 60 years old, from Greater Farasan, a sailor and fisherman, knew 15 types of songs sung on different occasions. He sang to us nabyas known as the dāna (the largest pearl) and another which accompanies the traditional zāmil dance. At Sayer village, Muhammad Hanas sang two nabyas using the zammil melody. He said that songs on board the dhow were sung accompanied by drums and dancing: two types of drum typical of the region were the zalfa, a hemispherical goatskin drum carried at the player's waist, and the elongated $z \bar{r} r$, made of earthenware and ox-skin, which stood on the ground and was played with two sticks.

Not far from Khutub village, the authors were entertained by the singer Mowwadh Khamisi, in his $50 \mathrm{~s}$, from the village's al-Sulm quarter. He played the simsimiyya, a type of stringed lyre, accompanied by Ahmed Atiyya playing a daffa (tambourine). The singer sang nabyas recollecting sea voyages, the sea captain and diving, all sung to the kāsir melody.

\section{Remembering Pearling}

Pearling in the Red Sea has attracted far less attention than that of the Arabian-Persian Gulf, whether from an ethnographic or historical-archaeological perspective. Exceptions include Londres (2008: 71-78), Miran (2009: 101-106), and Schörle (2014: 46-49). Pearl diving around the Farasan Islands took place on nine pearling beds (mazāri' or ma 'ädin). Muhammad al-Husayyal recalled that when he started diving at the age of ten, "the divers used to set out on a planked hüri for some 20 days, pitching a tent on one island or another". He added that all but one of his fellow divers had by now passed away.

Our informants recalled that much of the pearling and nacre collection by Farasanis in the last century had been conducted around the Dahlak Islands, which were richer in both than the Farasan Islands. Sanbūks carried from 20 to 120 divers and haulers in equal numbers, all of whom also crewed. Crossing to Dahlak took some $24 \mathrm{~h}$ in fair winds, but longer if unfavourable wind conditions obliged them to row. Sheikh Muhammad Isa 
Muhammad Aqili, 76 years old, who had spent 60 years in pearl diving, and whose father was a pearl diver, recalled ten locations around the Dahlak archipelago where Farasanis pearled (Fig. 1e). Many Farasani sanbüks sailed there, he said. The largest, he recalled, was 30-40 m long by 10-12 m wide, and had two masts. Smaller, single-masted vessels of about $20-25 \mathrm{~m}$ in length and $4 \mathrm{~m}$ wide were used around the Farasan Islands, he said. The Dahlak islands had many pearling beds, according to Soleiman Mohammed Ali Baloos, ${ }^{28} \mathrm{a}$ 35-year-old from Farasan town who still traded pearls, relating the experiences of his late father, a pearl diver and later trader who had died 12 years earlier (Fig. 17b): "the types of pearls there were of superior quality".

Ibrahim Muftah recalled that the Dahlak islands attracted divers not only from the Farasan Islands, but also the Yemeni coastal towns of Madi, Salif and Hodeidah. Ali Khalifa, a former diver, reminisced about the relationship between Farasanis and the Dahlaki divers and their financial arrangement: "There was some agreement with the [Dahlaki] locals to work together, but there are no written records", he recalled. "In general, Farasanis had amicable relations with Dahlakis", and shared the resource. This is perhaps comparable with the situation in the Arabian-Persian Gulf were, by tradition and backed by colonial enforcement, the pearl oyster beds were held in common by all of the coastal people of the region: boats of different towns, tribes and emirates were expected to fish amicably on the same banks. Ali Khalifa recalled that several Dahlakis had also chosen to settle on the Farasan Islands, and likewise Farasanis sought employment on the Dahlak archipelago or the Eritrean mainland: this exchange was stemmed by stricter immigration measures introduced during the Italian occupation of Eritrea (1890-1941) and following the formation of the Saudi kingdom in 1932.

\section{Pearl Diving}

Diving (al-ghọs) usually took place during the cooler months, when optimum weather and visibility prevailed, unlike in the Arabian-Persian Gulf, where diving took place in the summer (Agius 2005: 145-146). A single pearling journey (jawsh), lasted 2-3 months. But sometimes pearling went on throughout the year, with up to three diving trips in 12 months. The search for prospective pearl beds could take far longer than the actual time spent diving. Sometimes Dahlak trips produced no results at all.

Sheikh Muhammad Isa Muhammad Aqili, 76 years old at the time of our interview, and with 60 years of pearl diving experience, recalled that there were 12 Farasani pearling and shell-collecting sanbūks at the time he was active. Each carried a dugout or plank-built $h \bar{u} r \bar{i} \mathrm{~s}$ on board which carried two or three divers each: he said, a number of divers searched a prospective area, searching for (yubayyinü) a good oyster bed, while other divers collected shells in shallower waters for nacre. The best location for collecting shells was at Ras Hafun, Zayla, Barbara on the Somali coast, as well as Djibouti and Sudan, Sheikh Muhammad recalled. After months at sea divers and haulers returned home for 10-15 days to rest and be with their family; they would then return to diving.

Around the Farasan Islands today, pearl oyster shells (bilbīl or mahār or Far. gumāsh; Pinctada radiata, Bosch 1989: 83) are found in limited quantities around the islands of Qumah, Saluba (سلوبه) and Dumsuk, and in the Khor Ma'adi. Our informants recalled that there had been nine pearling beds around the Farasan Islands, but they were vague about the location of most of these. An elderly diver, 90-year old Ali Khalifa Ali Hammed Damri remembered one called al-'Ayn (العين) in an area $1 \mathrm{~km}$ south of Dumsuk island. There were

${ }^{28}$ Interviewed on 13 January and 14 May, 16 May and 18 May, 12 January and 21 May 2010 respectively. 
others, he said, but these "were less productive." Guided by Abdo Aqili we prospected traditional pearling sites at Abu Sharaya, to the east of Greater Farasan, where his father had dived, and at Abu Shok and Abu Hummad. Meanwhile our observation of contemporary pearl diving in action (see below) was in the northern reaches of Khor Ma'adi. Abdo Aqili said that conches were also sought in Khor Farasan. No informants recalled the locations of pearling beds further afield, on the Dahlak islands.

Diving for oyster shells started roughly at 7 or 8 a.m., and continued until noon or 2.00 in the afternoon, when the $n \bar{a} k h \bar{o} d a$ raised a flag (bayrak) to signal the end the diving. They were long and exhausting hours, our informants recalled.

The more complex and intensive form of the pearl fishery, which ceased with the discovery of the culture pearl, involved pairs of divers and haulers in deep water, often working in large numbers and in teams which took turns while others rested to maximise productivity (Carter 2012: 261-262). The diver descended to a depth of 10-15 bā' (18$27 \mathrm{~m}$ ) using a weight (thaqqāla or jalīla, julayla, or jawla) attached by a ring to a rope, the zayban, which he gripped with his right foot. A number of informants said that old Turkish cannonballs were often used for this purpose. Having descended, the diver released the weight, and the hauler hauled it back up. The diver then collected oyster shells in a rope basket (dangìl; Figs. 13b, 14, 15b), the handle of which he hung around his neck. This was attached to a second rope ( $i \bar{l} d a$ ), which the hauler held in his hand-in some cases, the 'ida was attached to a float (ramas). When the diver was ready to ascend he pulled the rope, and the hauler raised him. A typical dive would not exceed a minute, although some informants

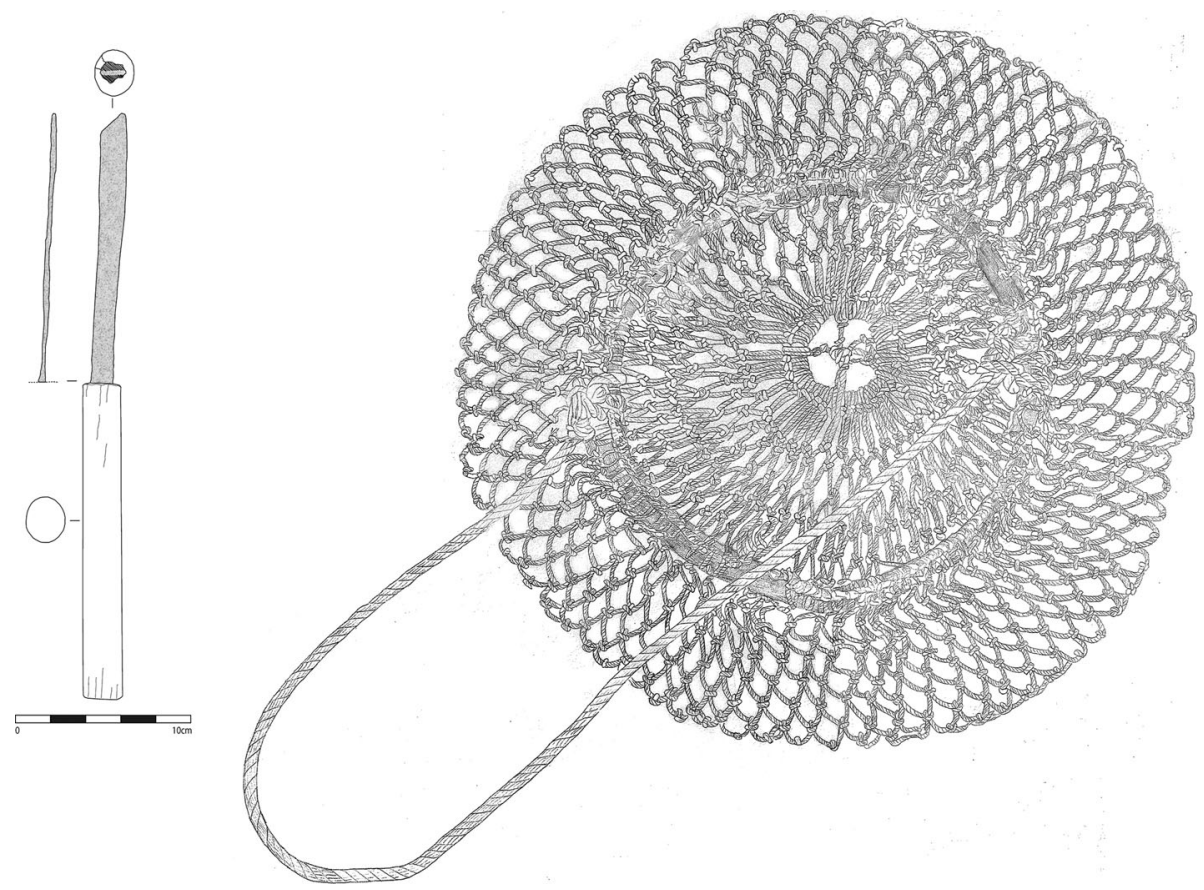

Fig. 14 Left A pearling knife (mufakka or mafakka) in the collection of Suleiman Baloos; Right a rope pearling basket (dangill) from the boys' primary school museum, Farasan town (Images: C. Zazzaro) 

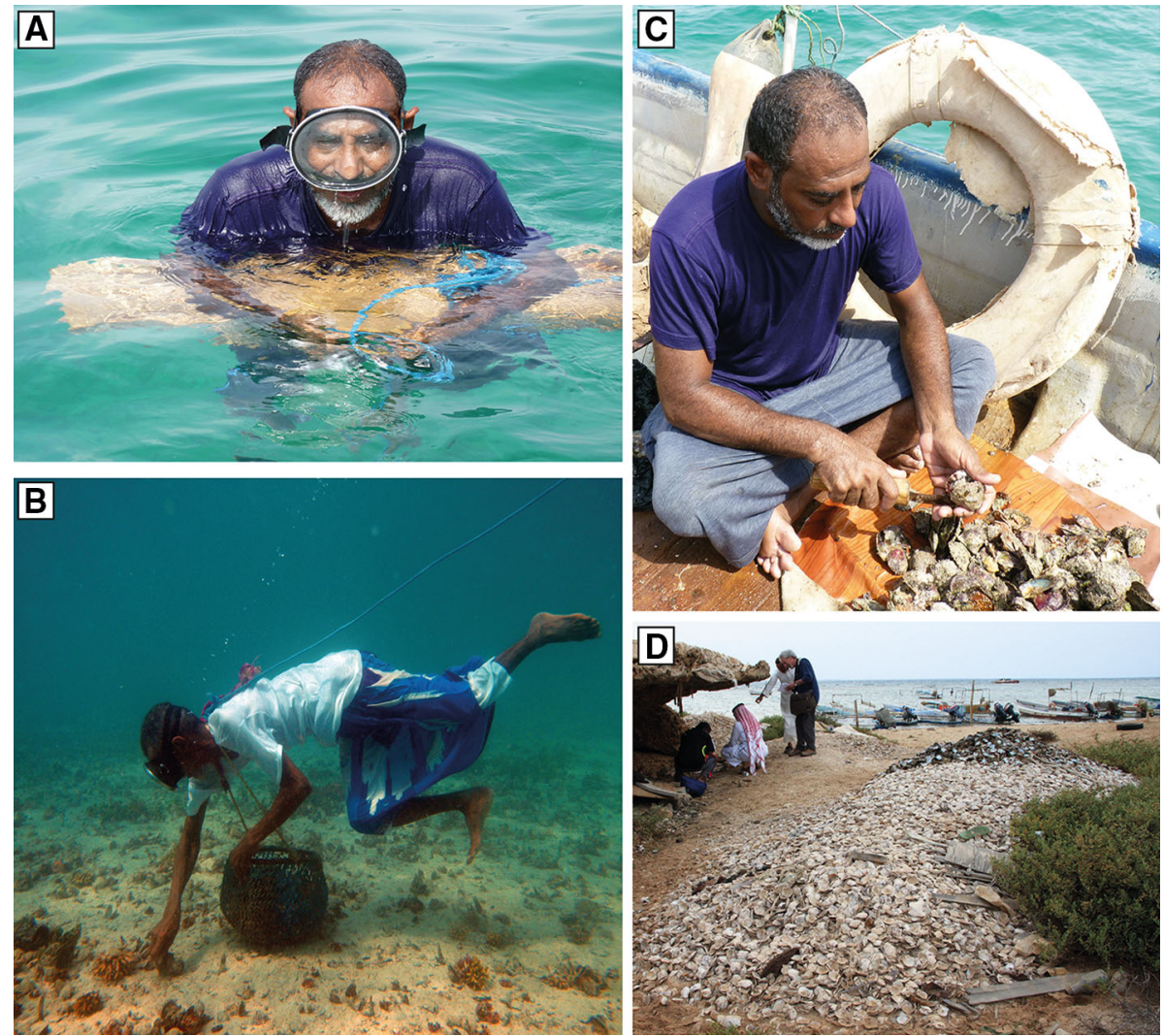

Fig. 15 Contemporary pearling demonstrated in Khor Ma'adi: a Ali Hasan Hammud Sharif resting on a ramas float between dives (Image: D. A. Agius); b Muhammad al-Husayyal diving for pearl oysters (Image: University of Exeter); c Ali Sharif opening pearls on deck (Image: D. A. Agius); d a contemporary oystershell midden and rock-overhang shelter at Khabs, Segid island (Image: J. P. Cooper)

remembered that some divers could dive for up to two. Divers wore finger protectors (khabat) made of goatskin. Some also used a nose-clip (khartüm).

The items of equipment and practices described by our informants appear identical to those of Arabian-Persian Gulf pearl fisheries, though the terminology differs in some instances (c.f. Carter 2012: 218-223).

In shallow water-ca. 2-6 $b \bar{a}^{\prime}(3-9 \mathrm{~m})$ - diving was usually from small boats and for nacre-bearing shells: a simple technique could be used without the use of a weight and hauler, so that divers could even work alone, although more typically two or three worked

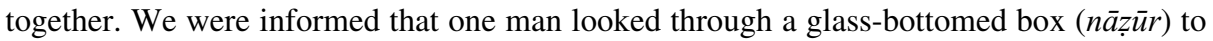
see the sea bed, while a second moved a hand-held sounding lead or stone (bild) to guide the diver to the location where the oysters or șadaf were spotted. When a hīrī was used for the this purpose, it was called a șadda $f$, or "sheller". After each dive, typically lasting up to $40 \mathrm{~s}$, the diver surfaced to rest on a ramas (Fig. 15a). For the largest shells, such as the spider conch (Lambis truncate sebae Kiener; Sharabati 1981: 44, 76; 1984: Pl. 9; Vine 1986: 135), he could collect no more than two at a time. This technique continues to be used to the present day among hobbyists, as discussed below. 
Informants told us that a fully grown oyster takes about 52 days to develop, a period known as muddat al-wasam. Without exception, divers and pearl merchants recounted their belief that a pearl is formed from a drop of rain water that falls onto the sea and descends, without mixing, into the open shell of the female oyster. We were also told that the failure of rains in the preceding rainy season would result in no pearls forming. This account is of long standing, for example occurring in al-Mas 'ūdī's 3rd/10th century Al-Mas ūdī (1983: I.168).

Soleiman Baloos, the pearl merchant, then 35 years old, recalled tales told by his pearldiving father of shark attacks. Divers were fearful of this risk, and hoped that dolphins would protect them. Baloos also remembered from his father that when deficient of vitamins (gishāsh), they ate the stalk and leaves of the kumthir plant: these had good nutritional value, he said, but added that the leaves of the "guava" were better. Divers sought out guava leaves against bacterial infection, inflammations and pain.

\section{Opening the Pearl Oyster Shells (Falk)}

On board the pearling vessel, each diver was assigned some space (Far. shagra or shigra) to deposit and open his shells. ${ }^{29}$ This separation of the yield indicates that divers operated independently in the Red Sea, at least in the later years of the industry recalled by our informants. In the more intensive Arabian-Persian Gulf fishery of the early twentieth century, it had been typical for divers to pool their oysters and take a share of the overall profits (Londres, 2008 (1931): 86). More detailed sources for the Gulf indicate that independent divers did also exist in the early $20^{\text {th }}$ century, under the so-called ' $a z a l$ system, but they were not typical (Carter 2012: 199). Divers opened the shells using a knife (maflaka/maflāk or mafakk; Figs. 14, 15b). On opening a shell, the diver used the blade of the knife to probe every fold of the organism in search of a pearl. He would then gradually strip away the flesh, continuing the search as he went. If he was lucky and found one, he placed it on the back of his wet hand, and continued searching. Once several had been found, he placed them in a piece of cloth (mașarr) or red-cotton cloth (hârra; Fig. 17a, d), which he tied like a purse when he had finished. The search was not always successful: Ali Hasan Hammud Sharif, 49 years old of Khutub village, ${ }^{30}$ recalled that divers could spend days and even weeks opening shells without finding a pearl.

Among smaller-scale pearl divers operating on the Farasan Islands today, it is more typical to return the unopened shells to shore for opening, generating new shell moundsfor example at Khabs - to join others on the islands that are 5000-5500 years old (Fig. 15d; Bailey et al. 2013: 244-245). The flesh of the oyster was often eaten in soups, we were informed, a custom not shared with the Arabian-Persian Gulf, where the oyster flesh was usually thrown away. ${ }^{31}$ More typically, however, the only part consumed was the hard adductor muscle called the khart. $^{32}$

\footnotetext{
29 Information gathered from: Suleiman Mohammad Ali Baloos on 12 January 2010; Mohammad Abdalla Mohammad Abbas; Aqil Isa Hamadi Mohammad both former pearl divers from Qumah, interviewed on 23 May 2010, and Othman Humuq, 41 years old, a folklorist and historian from Khutub village, interviewed on 16 May 2010.

30 Interviewed on 22 May 2010.

31 Pers. comm., Ali Al-Ghabban, archaeologist, interviewed on 8 January 2010.

32 Interviewed Soleiman Mohammad Ali Baloos, 35 years old, pearl merchant on 12 January 2010; Munawwar Aqili, 75 years, a pearl diver on 17 May 2010. Nacre gathered in the Red Sea is sold to Italy while in the Arabian-Persian Gulf it is thrown away; information gathered from Ali Al-Ghabban 8 January 2010.
} 


\section{Collecting Shells}

Ibrahim Muftah and Suleiman Baloos recalled shells (qawāqi', s. qawqa) other than pearl oysters that were also collected, mostly for nacre. These included:

a. Pen shell (Atrina vexillum Born), a large black bivalve found only at depth (Sharabati 1981: 81, 83, 1984: Pl. 41; Vine 1986: 134; Sturman et al. 2014). The shell was processed into jewellery (Fig. 16a); Suleiman Baloos told us it also produced black pearls;

b. Topshell (kukyān (Far. hawța); Tectus dentatus Forsk.; Sharabati 1981: 74, 75, 1984: Pl. 3; Vine 1986: 127). The shell has "an especially thick lining of mother-of-pearl, which was collected [in the Red Sea] and cut for shirt buttons ..." (Sharabati 1981: 75) (Fig. 16b);

c. The spider conch, collected principally for nacre, but which occasionally, we were told, yielded pearls (Fig. 16c);

d. Rukhum (Far. wada ; Atys cylindricus Hellbling; Khalil 2012: 1242-1243; Sharabati 1981: 93, 95, 1984; Pl. 34), collected by women to make jewellery and sewn-on decoration, and exported by the sack-load (Fig. 16d);

e. Venus comb shells (luham or liham; Murex tribulus L.; Sharabati 1981: 93, 95, 1984; Pl. 17; Vine 1986: 140). The shell was harvested for its nacre and its operculum (see below); because of its long syphonal canal, it was also used with its spines broken off as a feeder (murja) for babies who were unable to suckle (Fig. 16e-left);

f. A large conch (lakhu; Strombus bulla Röding; Sharabati 1981: 81; 1984: Pl. 8). The shell was harvested for its nacre and operculum (Fig. 16e-centre);

g. Likiz (Murcidae sp.(?)) Again, harvested for its nacre and operculum (Fig. 16e-right);

h. Tulip shells (bisir or busur; Fasciolariidae Sp.; Sharabati 1981: Pl. 23; 1984; 73; Vine 1986: 141). Harvested for its nacre.

The kukyān, and other shells collected for their nacre, were weighed in kilos, and placed in tanakas (metal tanks). The $n \bar{a} k h \bar{o} d a$ then sold them to a trader by the qintār ("a varying weight"), who exported them to destinations including Aden, Ethiopia (before Eritrean independence), and Sudan. Conch and topshells were crushed for their nacre to manufacture ceramics, buttons, and jewellery such as earrings.

Ibrahim Muftah said that the small rukhum shells were still collected by women on Qumah Island today ${ }^{33}$ : they covered wooden planks with a substance, place them in shallow water where the shells were known to gather, and left it there for one or more days. The Atys cylindricus molluscs would then crawl in quantities onto the wood and stick to it. The women then collected the wood and scraped the shells into buckets of hot water to kill the organism. When dried, Ibrahim Muftah said that the shells were "struck like a match" to create small holes at their ends in readiness for stringing into necklaces or to decorate objects such as boxes or cushions (Fig. 17e). Atys cylindricus were also exported.

Other marine products included turtleshell (dabal) for which Farasanis hunted, and also ambergris ( 'ambar), which occasionally washed up on the beach. One informant related his belief that ambergris was the product of an underwater "tree" that whales ate, rather than being from the whale itself-like the formation of pearls from raindrops, an accepted folkloric explanation.

33 We were informed by the Governor of Farasan, Al-Muhandas Abd al-Rahman Abd al-Haqq (15 May 2010) that there is a Women's Cultural Committee (Lajnat al-Thaqāfiyya al-Nisā'iyya) that deals with handicrafts, but we were unable to visit them. 

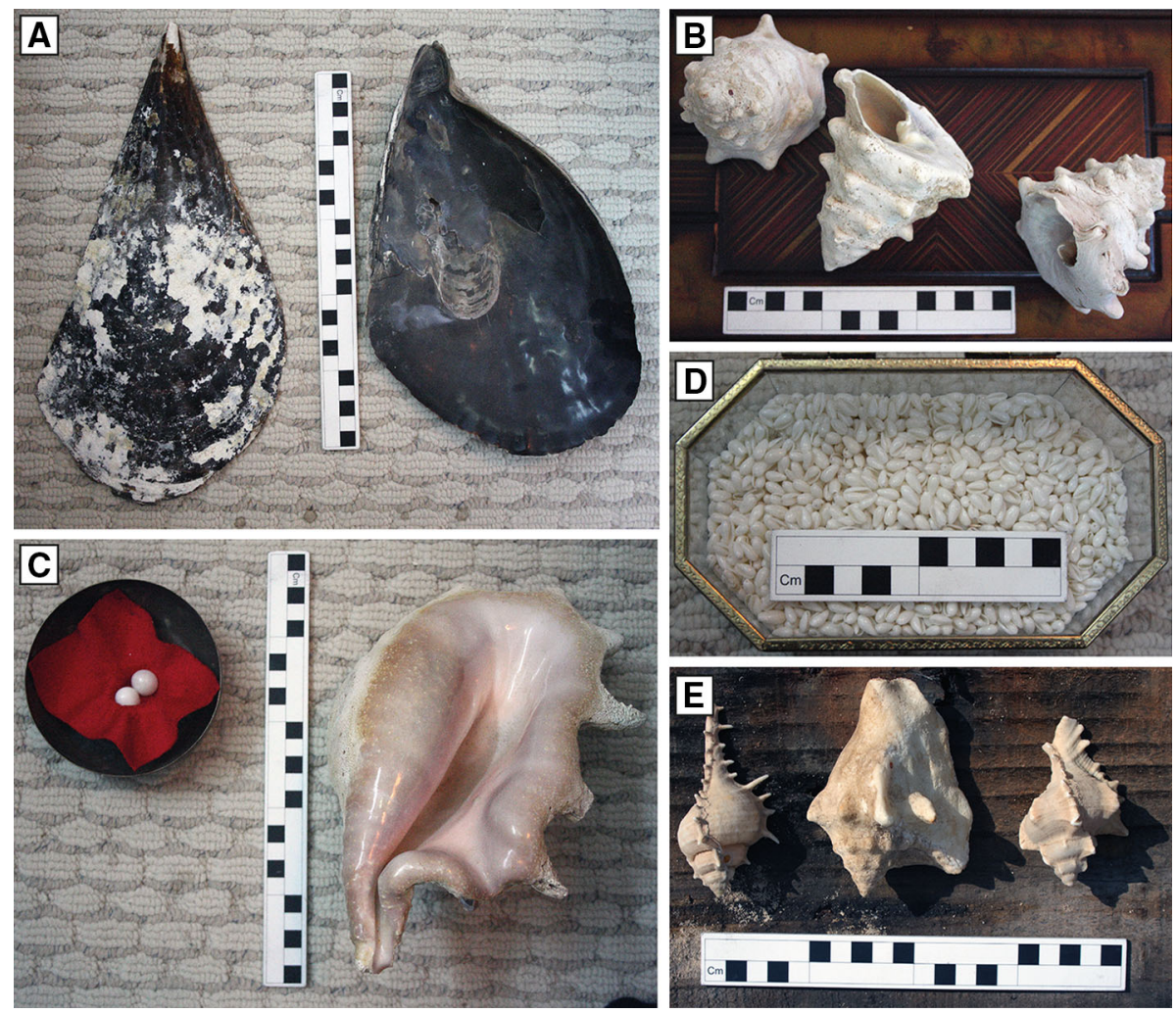

Fig. 16 Shells in the collection of Sulaiman Baloos: a Pen shell (Atrina vexillum); b Topshell (Tectus dentatus); c Spider conch (Lambis truncate sebae); d Atys cylindricus shells, collected by women, used to make jewellery locally and exported; e Shells, from which opercula were extracted for hair-dressing compounds, shown to the authors on the beach at Sadayn: Left luham or liham (Murex tribulus); Centre lakhu (Strombus bulla); Right likiz (Murcidae sp.(?)) (Images: J. P. Cooper)

The tough operculum (zufur) of the likiz, luhum and lakhu was ground up with the thamra flower and perfumes added to it; the resulting paste was rubbed into the partings (mafāriq) of women's hair on special occasions. Possible perfume additions included jannat al-na 'ìm and rụh al-rūḥ; a ground red stone, huṣn, was sometimes added to give colour.

\section{Hobbyist Pearl Diving Today}

Pearl diving activity on the islands is today very limited. Abdo Aqili, our SCTA guide, recalls diving from the age of eight, having learned from his father. He also told us that there were some 15 active divers, including himself, left in the islands. They did this as a hobby, since their main occupation was fishing. The authors went on two diving expeditions with local divers in order to observe their activities. The first was with Abdo Aqili and his brother Isa on their fibreglass falūka, which they keep at Tibta, to pearling beds at Abu Sharayal, an island east of the modern ferry port, where they had dived several years earlier. No oysters were found. Success was achieved 2 days later, this time with an expedition from the anchorage at Khabs, $2.5 \mathrm{~km}$ northwest of Khutub village to the 

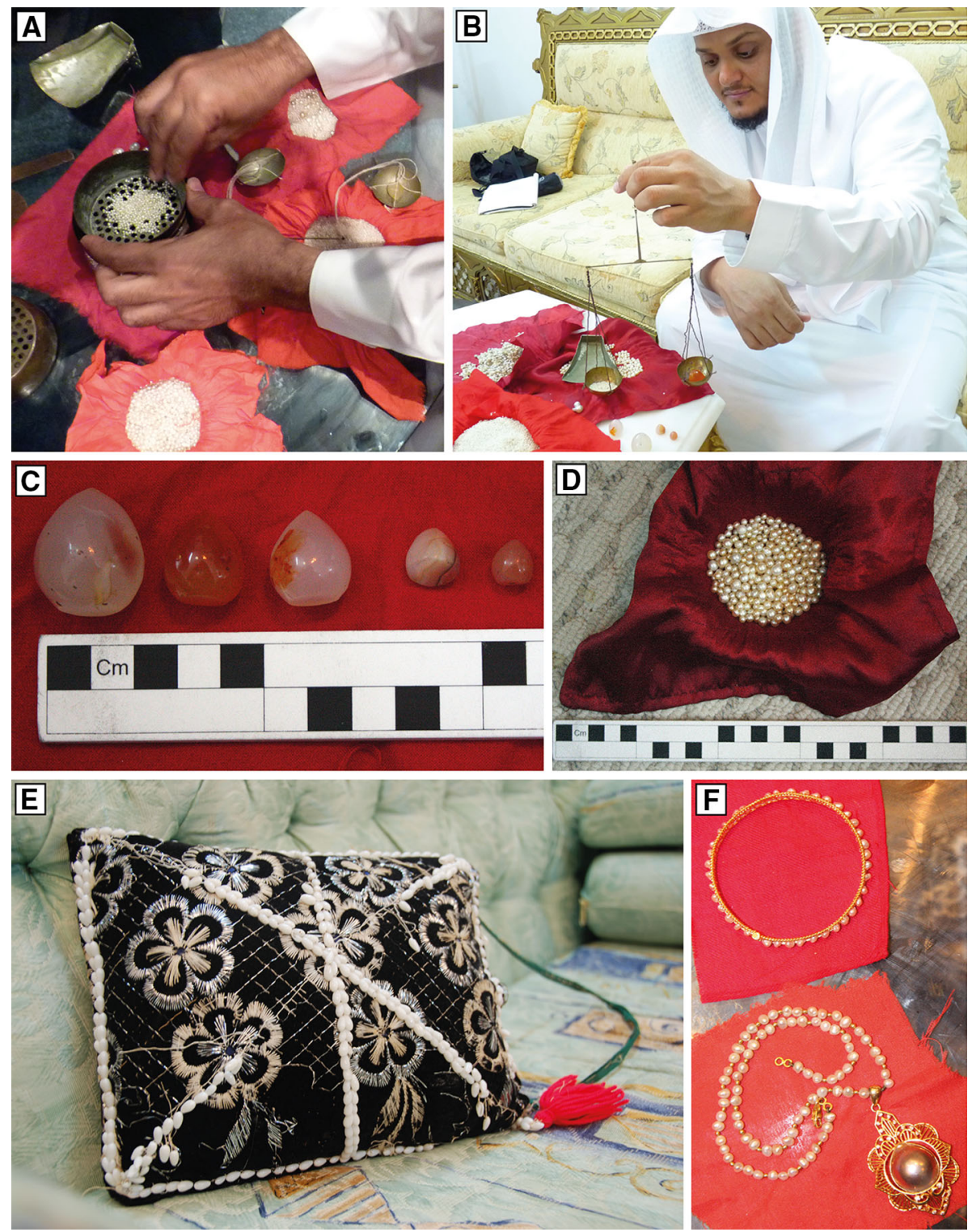

Fig. 17 Remembering the pearl merchant: a Sieving pearls, demonstrated by Sheikh Muhammad al-Rajhi (Image: D. A. Agius); b The pearl balance, demonstrated by Sulaiman Baloos (Image: D. A. Agius); c Agate pearl weights in the collection of Sulaiman Baloos (Image: J. P. Cooper); d Mixed pearls in a red cotton hārrra (Image: J. P. Cooper); e Cushion decorated with Atys cylindricus shells (Image: Peter Harrigan); f Gold jewellery incorporating pearls, in the collection of Sheikh Muhammad al-Rajhi (Image: J. P. Cooper) (Color figure online)

northern reaches of the Khor Ma'adi. Ongoing pearl diving out of Khabs was evidenced by mounds of opened oyster shells-some evidently recent, under the shade of an overhang in the coral bedrock (Fig. 15d). Divers Muhammad Abd Allah Said al-Husayyal, 69 years old (Fig. 15c), and Ali Hasan Hammud Sharif, 49 years (Fig. 15a-b), took us to the pearl beds, 
in about $3 \mathrm{~m}$ of water, and gave us a demonstration. The method of diving and collecting shells was different in several respects from that used when diving from sanbu $k \mathrm{~s}$ in the past, not least because diving is conducted from a fibreglass fishing falüka. Divers use a modern, glass-fronted diving mask which covers the nose, and so does away with the need for a traditional nose-clip: the diving is nevertheless done with breath held, and without the use of a SCUBA unit, snorkel or fins. The diver enters the water with a dangil basket attached by synthetic rope to a ramas float. During his first dive, the diver swims to the bottom with the basket, leaving the ramaș on the surface. At the bottom, he loops the handle of the basket over his head, and begins to collect pearl shells, placing them in the basket. A single dive by Muhammad al-Husayyal lasted on average $35 \mathrm{~s}$ : all dives fell within a relatively narrow range of 30-40 s. At the start of the diving the basket was light, and Muhammad managed to put an average nine handfuls of oyster shells-either individuals or clusters - into the basket. During this period, he was swimming with both feet off the seabed. To surface for air, he would leave the basket on the sea bed and push off with one foot, rising hand over hand up the rope to the ramas. At the surface, he would rest on the float for just under a minute before descending. On each subsequent dive, he would use the rope to haul himself down again, swimming as he did. Hauling down became more effective as the basket below became heavier with oysters after each successive dive. However, a heavier basket meant that Muhammad could no longer free swim once it was around his neck, and he had to walk himself along the bottom with one foot, raising and dropping the basket as he went. During this phase of the diving, the average number of handfuls of oysters collected fell to less than five: the duration of his dives did not change, but the rest time almost halved to a typical 30-35 s. The total number of dives made before the basket was filled was more than 30 . When it was full, Muhammad surfaced to the ramas, and then swam with it to the boat, where he handed the rope to a man on board, who hauled the basket in. Again, we note the difference between this diver-and-float technique, typical of a small-scale "cottage industry" fishery, and the diver-weight-and-hauler technique used in the larger-scale, deeper water fishery that dominated at the height of the industry, memories of which were evidently still alive in the testimony of the older informants in this study.

In contrast to the accounts of our interviewees, the divers opened the shells on board while Abdo Aqili and his brother Othman sang work songs related to shell opening-but this was under the constraints of our filming schedule, and was not necessarily indicative of alternative practices.

Beyond the equipment of the hobbyists who continued to practice a modified form of pearling, few of our informants retained material mementos of their working lives as divers. On Greater Farasan, the 75-year-old Munawwar Aqili brought from under his bed a memento wrapped in a piece of cloth. He unwrapped it to reveal a pearl that he had kept from his days as a pearl diver in the Dahlak islands. When we interviewed him, he was working as a fisherman and lived in a one-room shed, but the pearl served as a reminder of his former life. ${ }^{34}$ And in Sayer, the former pearl diver Mohamed Hanas showed us the modern rubber-and-glass diving mask that he had used as a pearl diver. But otherwise, former working divers had not kept the tools of their former trade, leaving nothing to remind themselves or their families of their former lives.

34 Interviewed on 17 May 2010. 


\section{Pearl Merchants in the Past}

Pearl diving on the Farasan Islands was mediated with the outside world through a number of pearl merchants, the activities of whom were recalled largely by the 79-year-old Sheikh of Khutub village, Muhammad Abd Allah Al Rajhi (Fig. 1f), and the 76-year-old Sheikh Muhammad Isa Muhammad Aqili, of Farasan town. Both had been divers for many years before becoming merchants themselves.

Merchants travelled with the pearls they had bought to Aden and Bombay, or to the Arabian-Persian Gulf, particularly Kuwait and Bahrain. Perhaps not surprisingly, given the international nature of the trade, several pearling terms and terminology for weights and measures recalled by our informants are Sanskrit/Hindi or Persian in origin, just as in the Arabian-Persian Gulf (see Carter 2012: 289-303). The return journey by sail took merchants 6 months. Muhammad Hanas, from Sayer village, had known both sea captains and pearl merchants. He recalled that traders preferred the sea route to the Gulf rather than the overland route because "the Hajj caravan routes were often unsafe due to Bedouin raids."

\section{Grading and Weighing Pearls}

Once gathered from the divers, traders graded pearls by size. The trader would pick them up using a metal scoop (maghrafa) (Fig. 18d), and then sieve (yifriz) them through a series of five sieves (tâsāt farz) (Fig. 18a), each with smaller diameter holes than the previous. These nested inside each other when not in use. The sieve with the largest holes caught only the dāna, the largest pearl. The next size down would catch the tăli ${ }^{\circ}$, followed by the mizwar - a type often mounted on a finger ring; then came the anșa $r$, the $n \bar{a}$ ' $i m$, and finally the very small diqqa. This terminology of size differs in most respects from that used in the Arabian-Persian Gulf (Carter 2012: 237-238).

We also met Muhammad Al Rajhi, ${ }^{35}$ the Sheikh of Farasan, in his $50 \mathrm{~s}$ (Fig. 1c), who had learned about pearl trading from his father, a former trader who had died almost 19 years previously, and who had travelled as a trader during the "British period" to Aden, Bahrain and India. ${ }^{36}$ Both he and Baloos boasted that Farasani pearls were of excellent quality, and that yellow-tinged pearls were much sought after. This may betray a certain local pride, however, since "from very early times the finest pearls in the world have been found in the Persian Gulf" (Lebkicher et al. 1960: 254; see also Agius 2005: 101, 103, 105108 and Carter 2012: 253). Indeed, both conceded that the most expensive pearls were judged by their whiteness, described as "pure" (șäfiya) while pearls that are speckled (bilnamash) or oval-shaped were of lesser quality and therefore less valuable: the market at the mercantile level was essentially a free one, with prices decided through negotiation: this was not the case between divers and merchants (see below).

Merchants used the mithqāl unit in weighing pearls. Ibrahim Muftah, Sulaiman Baloos and Sheikh Muhammad Hadi Al Rajihi showed us weights made of agate ('aqīq; Fig. 17c). The values of these weights in grammes recorded during this fieldwork are shown in Table 3, and display a mixture of two Indian pearl weight systems, the Bombay/Basri mithqāl and the Puna mithqāl (Carter 2012: 246-248), of which our informants did not indicate awareness. Most of the weights correspond to the Bombay series, except for a onemithqāl weight weighing $4.5 \mathrm{~g}$, and two two-mithqāl weights weighing $9 \mathrm{~g}$, which appear

\footnotetext{
35 The Al Rajhis were well known merchants in the Kingdom of Saudi Arabia; members with a trading and exchange establishment in Jeddah, Yanbo al-Bahr and Jizan; see Carter (1979: 163-164, 166-169).

36 Interviewed on 13 January and 14 May 2010.
} 


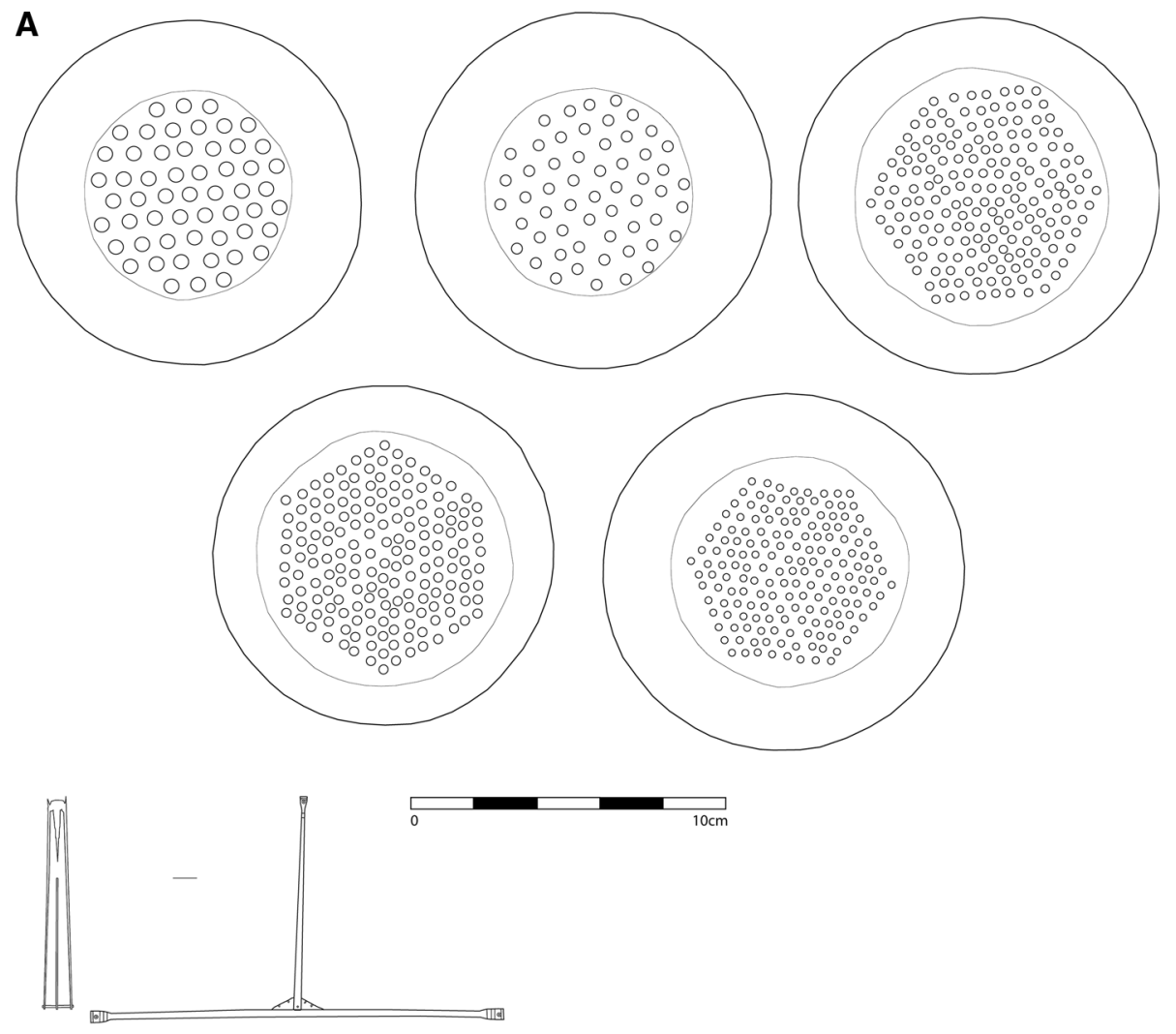

B
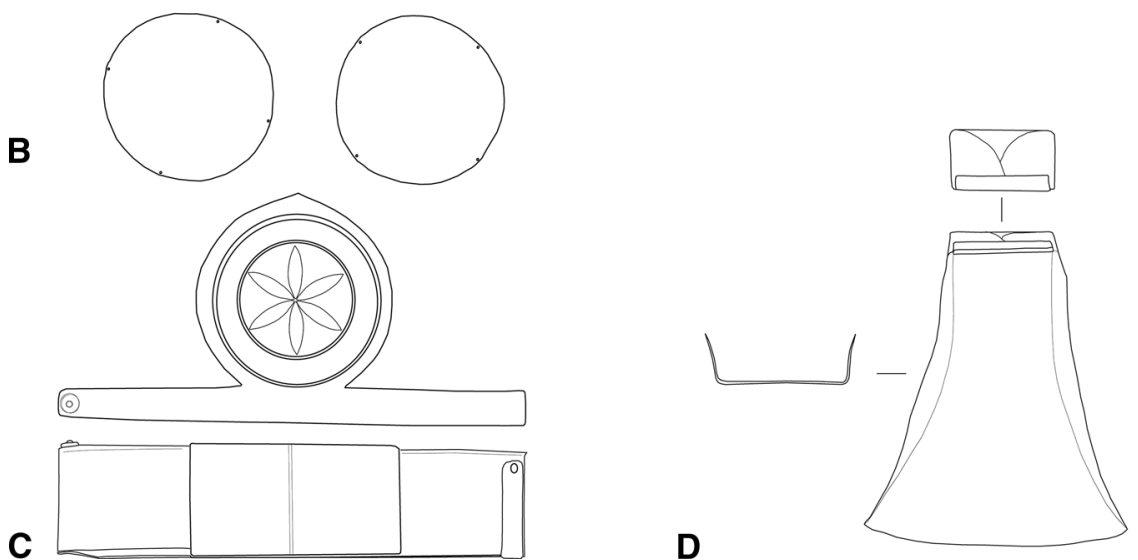

Fig. 18 Pearl trading equipment in the collection of Sulaiman Baloos. a Copper alloy pearling sieves: the hole diameters are, in descending order, 6, 5, 3, 2.5, and $2 \mathrm{~mm}$ (Image: L. Semaan \& C. Zazzaro); b Disarticulated copper alloy pearl balance and $\mathbf{c}$ its case, also copper alloy (Images: C. Zazzaro); d copper alloy pearl scoop (Image: L. Semaan \& C. Zazzaro) 
to be either of the Puna series, or perhaps a new standardised mithqāl value that was used briefly in the mid-twentieth century.

Our informants recalled that a unit system of Indian origin they called shaw (c.f. the Arabian-Persian Gulf chao in Carter 2012: 83-84) had also been used. They recalled that one mithqāl equalled 330 shaw, though historical sources and merchants active in the Arabian-Persian Gulf indicate that the shaw was in fact $330 \times$ the square of the mithqal (Carter 2012: 248). In practice, merchants used a book of tables to obtain the shaw value from the weight, rather than actively calculating it using this formula (see below).

Pearls were weighed using a brass balance (mīzān) and stored in a case (bayt al-mīzān; lit. "the house of the balance") (Figs. 17b, 18c). Today, merchants use electronic scales in order to obtain an accurate reading. We tested both the old and modern devices and we found that the balance gave almost as close a reading as the electronic scales-the divergences of the mithqāl series aside.

Pearl trading was active on a very limited scale at the time of our visit, with both Sheikh Muhammad Al Rajhi and Soleiman Baloos participating. The latter said he did business in Bahrain, "the only Gulf state that buys natural pearls." All the other Gulf States, he remarked, "cultivate cultured pearl banks on a small scale, but such pearls are of bad quality". Since the development of the culture pearl in 1934, Japan has been the leading player in the industry, and for many years has been its trading centre (Lebkicher et al. 1960: 254; Agius 2005: 105-107; Carter 2012: 178-179, 261-262).

\section{Personal Souvenirs of Pearl Trade}

A number of people retained a broad set of pearl trading memorabilia. Sheikh Muhammad al-Rajhi and Suleiman Baloos, the sons of pearl traders, and Ibrahim Muftah, the son of a pearl diver, each retained the core tools of the trader: a pearling scoop, agate mithqāl weights, a pearl balance with case, and pearling sieves. The brass case of Baloos's balance was inscribed with its place of manufacture, "Ahmedabad", in Gujarat-identical to numerous examples recorded from the Arabian-Persian Gulf region (Carter 2012: 235). All also possessed loose pearls tied in red cloths. In addition, Sheikh Muhammad showed us his well-worn copy of Kitāb al-La'āli', or "Book of Pearls", by Muhammad al-Qādī (1928), a pearl-trader's chao (shaw) book-a well-known edition, and the most frequently surviving version (Carter 2012: 242-243). He also brought a gold necklace and bracelet incorporating pearls (Fig. 17f). Baloos's collection included a range of shell species from

Table 3 Weight in metric of the mithqal weights owned by Ibrahim Muftah and Suleiman Baloos

\begin{tabular}{|c|c|c|c|c|c|c|}
\hline \multirow[t]{3}{*}{ Mithqal weight } & \multicolumn{5}{|c|}{ Metric equivalent (g) } & \multirow[t]{3}{*}{ Average $(\mathrm{g})$} \\
\hline & \multicolumn{5}{|c|}{ Owners } & \\
\hline & \multicolumn{3}{|c|}{ Ibrahim Muftah } & \multicolumn{2}{|c|}{ Suleiman Baloos } & \\
\hline Quarter & 1.35 & - & - & 1.29 & & 1.32 \\
\hline Half & 2.49 & - & - & 2.37 & & 2.45 \\
\hline One & 4.50 & - & - & - & & 4.50 \\
\hline Two & 9.70 & 9.00 & 9.01 & 9.80 & 9.72 & 9.446 \\
\hline Five & 23.83 & 23.79 & - & 23.94 & & 23.853 \\
\hline
\end{tabular}


which pearls, nacre, or opercula were extracted, as well as oyster and conch pearls, and a cushion decorated with Atys cylindricus shells (Fig. 17e). What unifies these collections, and the selection processes they imply, is that they constitute the prestigious paraphernalia of the industry - that of the relatively wealthy trader-rather than items that invoke the hardship of the pearl diver's life. Here, processes of remembering and forgetting skew the material mnemonics towards more palatable aspects of the past.

\section{Finance}

According to the Aramco Handbook (Lebkicher et al. 1960: 254) the Red Sea pearling industry was subject to government taxation at home ports. This was $10 \%$ on "gem pearls" and "a share of the catch" on common pearls. In the latter case, this meant that the government received the same share as one diving crew member on a given vessel. Registered pearling vessels were also taxed. However, Suleiman Baloos recalled no taxation on pearling, perhaps suggesting that such procedural information had not been passed on intergenerationally.

A number of informants recalled aspects of the financial arrangements underpinning a pearling excursion. Sheikh Yahya Ibrahim al-Najdi, a former $n \bar{a} k h \bar{o} d a$, in his $70 \mathrm{~s}$, recalled to us that, before departure, divers sought loans to cover their own on-board expenses, and also the keep of their families while they were at sea. ${ }^{37}$ One version said that the captain, ship owner or a merchant advanced a loan (saläf) to the divers to cover the costs of food, clothes and accommodation, including for their families. Shaikh Muhammad Isa Muhammad al-Aqili recalled the names of some of the lenders of his day: Omar Sayigh, "a trader in the suq"; Ibrahim ibn Ibrahim al-Najdi, "from Tamim"; and Ibrahim Muhammad al-Rifa i. Divers were free to buy their own food and cigarettes for the season or pay to partake communally on board.

The amount loaned was then paid off via the diver's earnings during the season. Soleiman Baloos, the young pearl merchant, related his late father's account that a diver could go and work for another captain, but only after he had cleared any debts with the first: there was always a risk that he might not get the price for his pearls that he was expecting, and so end the season indebted. ${ }^{38}$ This was a common scenario, and would require the diver to return to the same captain the following year. It created, in effect, a system of indentured servitude. As Suleiman Baloos characterised it: "the diver was the possession (mamlük) of the trader." Moreover, when he died, a diver's obligations passed to his heirs. One former diver, the 74-year-old Mohammed Abdalla Ahmed Nasib from Greater Farasan, recalled: "My father was in debt; seeing him in a poor state, I worked hard for 2 years and succeeded in paying off his debt": he presented this as a remarkable story. It was not a common one: at the end of his narrative he stated that the diver "was poor, and died poor".

Informants recalled differently the number of working days in the week for the diver at sea: some said that both Fridays and Saturdays were rest days, while others recounted that divers worked all week without respite. Most, however, reported that Friday was the rest day. On days off, divers rested on board, or went ashore when this was possible. The former diver Muhammad Uthman Hanas of Sayer village recalled that during the fasting month of Ramadan the working day was altered to fit their religious duties and festive

\footnotetext{
37 Interviewed on 24 May 2010.

38 Interviewed on 21 May 2010.
} 
days. ${ }^{39}$ The pearling season always began in April, but the precise date of departure was timed to coincide with the beginning of the monthly lunar cycle.

Several informants recalled the method of distributing the pearling catch on a vessel. This was effected according an agreed ratio of days within the week, according to which the pearls went either to the divers who found them or to the captain or vessel owner. This was called the khumsī (pl. akhmās), a term which implies a system based on a five-day cycle: divers could retain the pearls they collected during the first 4 days of the cycle, while on the fifth the pearls reverted to the captain or ship owner for hiring the sanbuk . Muhammad al-Husayal recalled that this principle also applied to sadaf collection. ${ }^{40}$

On board the dhow, the $n \bar{a} k h \bar{o} d a$ would register any pearls he was given on the fifth day, and also kept a record of the name of the diver and the pearls that he had collected, together with their weight and type, in a ledger (daftar). Likewise he recorded divers' debts in the ledger; such ledgers, we surmise, have been lost or destroyed as no informant could give any information about their whereabouts: they have not become part of the saved assemblage of material mementos of pearling on the islands. The captain sold his pearls directly to the merchant at market price. The haulers, meanwhile, were hired directly by the divers themselves, according to a private arrangement. The hauler's payment was called a $n a s f a$, interpreted as half the amount that the diver received: it was not clear whether this was before or after debt repayments were made to the $n \bar{a} k h \bar{o} d a$ or owner.

Other divergences in memory revolved around whether a diver was required to sell his pearls directly to the ship's captain/owner, or whether he could keep them until he arrived on shore and sell them via a broker (dallāl) in the souq. One informant recalled that the divers were free to do as they pleased with their own share of the pearls. Sheikh Yahya Ibrahim al-Najdi, a former nakhoda of Farasan recalled that: "a diver who was not happy with the captain's offer for his pearls was then free to go to a pearl merchant in the hope of a higher price". ${ }^{41}$ If he was successful, then the diver would return to the captain or owner with the pearls tied in a cloth, in order to negotiate a higher price. The process was based on trust, since there was no thing to stop the diver from tampering with the pearls in the meantime.

A diver was expected to honour his undertaking (yamin) to give all pearls from the fifth day of diving to the captain. However, informants did recall that divers sometimes sought to hide pearls and sell them elsewhere. Suleiman Baloos recounted what happened when it was believed that a pearl had been stolen: "the $n \bar{a} k h \bar{o} d a$ would pass around a basket (zanbill) made of palm leaves and ask each sailor to place his hand in it". The idea was that if anyone had stolen a pearl, this was their chance to return it to the basket without anyone knowing: a tactful approach that depended on a repentant sailor.

The divergences in memory recounted by informants above are not necessarily due failures or inaccuracies of memory. They may reflect the different ways in which a diver could be employed in the pearl fishery. In the Arabian-Persian Gulf, various systems were followed. According to the salafiyya, system, loans were made to the whole crew, who then pooled their output, and were rewarded in a system of shares of the net profit. In the Gulf's khums system, a consortium of divers would combine their resources to equip a boat without necessitating a loan, and would either distribute profits between themselves by share, or act as independent divers when on the boat. Meanwhile, in the 'azal system, divers worked independently on the boat, opening only his own oysters and managing their

\footnotetext{
39 Interviewed on 24 May 2010.

40 Interviewed on 22 May 2010.

41 Interviewed on 24 May 2010.
} 
sale himself (Carter 2012: 192-199). It may be that all three systems were also use in the Red Sea. But here the system is far less well documented, and it is largely on fragmentary memory that our knowledge of the financing of pearling is based.

\section{Forgetting Places}

Farasanis from several islands spent time in the resort village of Qusar (قصار) during the "humid" season (mawsim ar-rutb); this lasts about 3 months during summer, culminating in the date harvest. The village, we were told, was abandoned some 40-50 years ago: Ibrahim Muftah told us that the islanders found no reason to stay there once they had electricity and with it air conditioners in their main homes. Some people today believe it is haunted by jinn-invisible, intelligent fire spirits that are part of Islamic cosmology.

Qusar had several wells, and was ideal as a summer resort, enjoying relatively cool breezes. The men met in each other's home: some evenings a story teller recounted stories of distant past and recited poems he knew from the ancestors. Some stories were about the genies and other spirits that haunted the houses.

At Khutub village there is a place called Ayqat al-Arayis (عيقة العرائ), a small promontory where informants recalled that the wives with children and new brides hailed the mariners on approaching land after absences of up to 3 months. Muhammad Al-Mahdi recalled return of the pearling fleet $(\operatorname{sinj} \bar{a} r)$ to the shores of Khutub: "the women ululated accompanied by songs and hand clapping". He added: "This was also the place where pilgrims were seen off by their wives."

\section{Communal Remembrances}

While individuals remember their past involvement in maritime life, and sometimes share their recollections with others, social activities that seek to construct a notion of maritime heritage are few and far between on the Farasan Islands and in Jizan. Those that exist largely do so outside the realm of official Saudi heritage agencies.

The most concerted attempt on the islands to assemble artefacts marking the maritime past takes the form of a modest museum within the main boys' primary school of Farasan town, which staff had established at their own initiative (Fig. 13). The authors were welcomed warmly by the head and teachers, and shown around by Muhammad Isa Ali Muzaffar, a teacher in his $40 \mathrm{~s}$, full of enthusiasm for the maritime past. The museum occupies a single large room within the school building, and, we were informed, is not open to the public, or to women at all. Nevertheless, artefacts displayed there enable pupils and visitors to view evidence of past life on the islands. A small number of maritime ethnographic artefacts are grouped together, fixed to the walls or on the floor, and normally labelled with a single word: "oyster-opening-knife", "oar", etc. (Fig. 13b). Unlike the trading-related items favoured by private collectors in the islands, the school museum contained artefacts of relatively low monetary value, and largely related directly to the pearling and fishing activity: a pearl-diving basket and oyster-opening knife; two glass demijohns and an earthenware $m \bar{a} ' \bar{u} n$ amphora (Fig. 13c); a fishing cast-net and a marine fish-trap (sakhwa, pl. sakhāwī; (Fig. 13b). A partly-labelled model of a twin-masted, lateen rigged, double-ended vessel (Fig. 13d) and two smaller and cruder models of transom-stern vessels conveyed an idea of past watercraft. The artefacts are not contextualised, yet they are retained as vehicles of communal memory and memory-transmission, evoking an 
earlier way of life. By their inclusion in the school museum, they have become tools in "actively circulated memory", comprising "cultural messages that are addressed to posterity and intended for continuous repetition and reuse" (Assmann 2010: 99). Why this set of objects has become the vehicle for that messaging is related to their material properties, small size and low prestige and economic value on obsolescence: clearly a school is no place to preserve a full-sized ship, nor the likely depository of high-value objects, both of which become "forgotten" as material objects within the school's already sparse remembrance narrative.

Despite the prominence of maritime activity in the past of Jizan and the Farasan Islands, government engagement in conservation, tangible heritage creation or memorialisation of the maritime past has been limited. While the SCTA has considered maritime museums for both of Saudi Arabia's coasts, neither has yet been built. Instead, the most public objects for the signification of maritime associations were a series of installations at traffic junctions in Jizan and on the islands. Yet only one of these that we encountered showed an intention to evoke traditional wooden vessels, albeit without any attempts at conservation: in Jizan, on a traffic island at the busy interchange of the Prince Sultan Bin Abdel Aziz Road and King Fahd Road, three wooden transom-sterned rowing boats of lengths 4, 6, and $8 \mathrm{~m}$ had been arranged by the municipality as part of an installation - set on concrete cradles in front of a mirror-glass wall (Fig. 19c). Their location on a busy traffic island and lack of interpretation of any kind limited their function as heritage objects that could evoke specific commemorative narratives. Nevertheless, alongside other sculptures on roundabouts in the city centre which, taken as a whole, presented a broad notion of Jizan as a maritime-facing city. On one, a modern steel-hulled harbour vessel had been place on a cradle (Fig. 19a); on another a sculpture on a roundabout in Harbour Square comprised an admiralty-pattern anchor, a ship's wheel, and lifebuoys-none of them indicative of regional watercraft traditionstogether with three large oyster shells, open to reveal large pearls (Fig. 19b). In none of these cases was any explicit interpretation offered. On the Farasan Islands, meanwhile, only two public sculptures made reference to the maritime past of the islands. The first, at a junction leading to a hotel, evoked in general terms an 'obri hull, but with inauthentic square sails (Fig. 19d). The second was a crude representation of an indeterminate sailing vessel set above the road leading to and from the ferry terminal (Fig. 19f).

The islands' maritime associations were not entirely forgotten in official representations, however. The logo of the Farasan Governorate comprises a calligraphic representation of the word "Farasan" in the shape of a sailing boat (Fig. 19e), and two boat models at the entrance to the Governor of Farasan's offices in Farasan town repeated the maritime theme. One rested on a bracket above the main entrance to the building (Fig. 6g): its double-ended hull and curved stempost evoked a za ima, in the regional, southern-Red Sea sense of the word (Agius et al. 2010: 77, 2014: 149). Across the car park in a shelter, a cruder wooden model evoked a double-ended 'obrī (Fig. 6f). Again, no interpretation was offered with these models.

The authors encountered only one large vessel that was maintained, or at least retained, as an explicit heritage object: this was in a formally constituted Heritage Village at Suais (سويس), on the coast some $11 \mathrm{~km}$ south of Jizan port. The "village", of unknown foundation, comprised some examples of traditional architecture, a whale skeleton, and the vessel in question, which was moored in a lagoon. The boat was, according to its builder Ibrahim Bilghaith, a sanbük. Some survivals of this same type exist in Yemen, where it is a fishing and cargo boat, and referred to as an 'obrī (Agius et al. 2010: 77). The Suais vessel had been built to take an inboard motor, but the aperture for the propeller had been closed, and a short mast, broken yard and sail had been erected. While a relatively flimsy mast and 

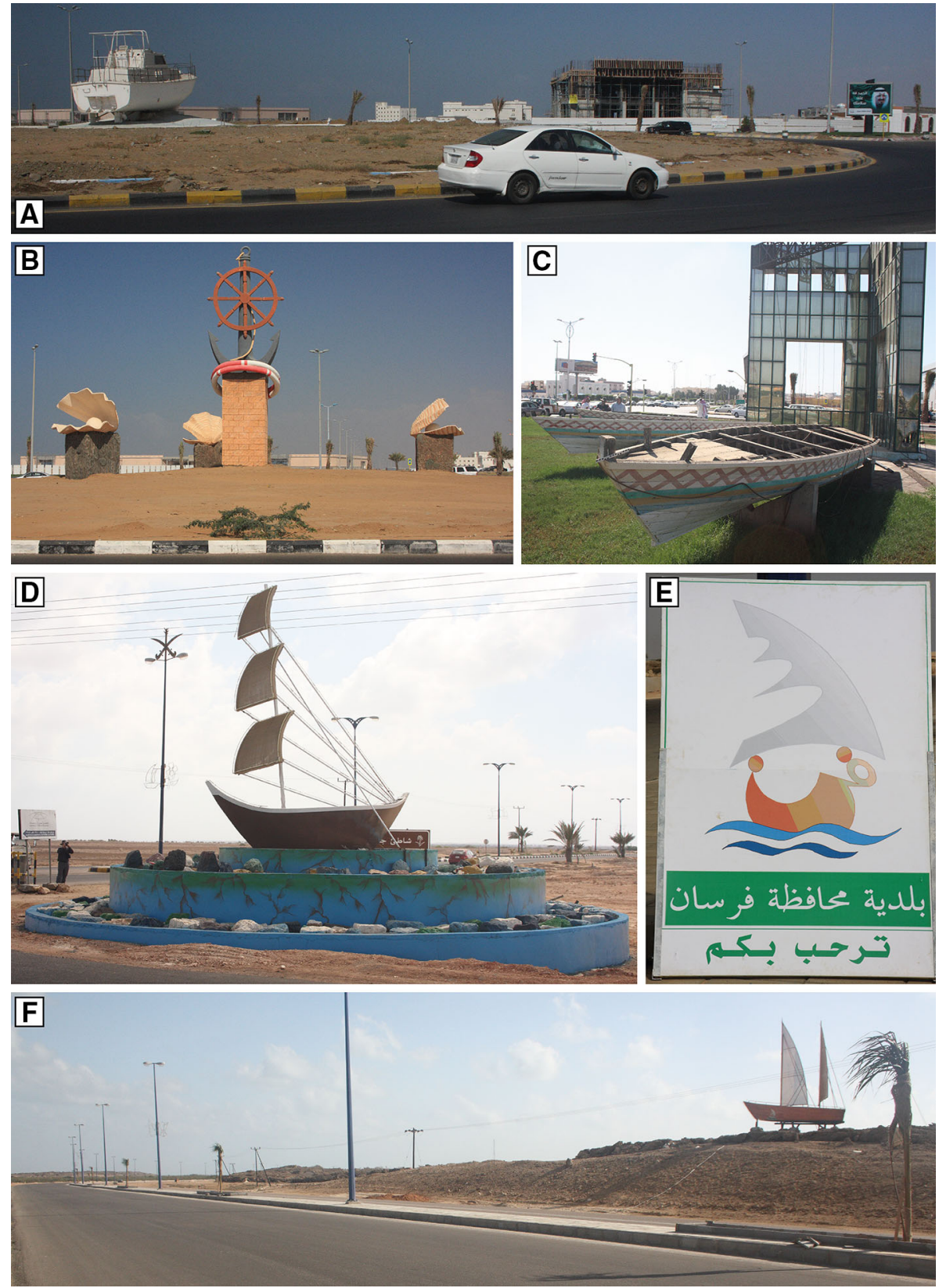

Fig. 19 Memorialising the sea: a-c Traffic islands in the city of Jizan, d Maritime-themed sculpture at the turn-off to a tourist hotel, Greater Farasan. The hull suggests an 'obrī; the rigging is fanciful (Image: J. P. Cooper); e The sailing-boat-shaped logo of the municipality of the governorate of Farasan; f A generic sailing boat installation on the road leading to the ferry terminal, Greater Farsan (Images: J. P. Cooper) 
sail is common among 'obrīs in Yemen as a back-up to the inboard engine, the fact that the propeller aperture on this hull had been deliberately closed up gave the impression of a fundamentally motorised vessel disguised as a sailing craft for its present purpose: in fact, Ibrahim Bilghaith showed us the removed engine in his yard. Meanwhile, the hull had been entirely decked over to create a platform onto which visitors could walk. There was no interpretation around the vessel-and no evidence, indeed, that the village was popular with visitors. In fact it appeared a "dead", or forgotten, heritage village.

While public art and heritage representations of the maritime past were few, only one small formal museum display was dedicated to the subject. This was in the SCTA's museum in Sabya (صبيا), one of several regional museums opened in the country in the 1980s. Sabya is on the mainland, $30 \mathrm{~km}$ north of Jizan. Among the archaeological displays were some vitrines dedicated to ethnographic subjects, one of which was maritime-themed. The display was dominated by a model of a transom-sterned, two-masted pearling sanbu $k$, some carpenter's tools, and photographs of harbour scenes in Jizan and the Farasan Islands. Brief narrative labels were dedicated to boat typology, the development of Red Sea boat technology, and pearling. There was no reference of significance to the communities building and using these boats.

Closer to the formerly maritime communities themselves, however, was an initiative by the SCTA to restore the traditional housing of the Farasan Islands associated with the pearling industry. Cuboidal houses, with fossil-coral walls and decorated stucco facing into a high, walled yard, are typical of vernacular architecture on the islands, and also redolent of styles found on the Tihama, notably at Zabid, in Yemen. While entire villages on the islands such as Qusar and Khola have long been abandoned, individual historic houses, particularly in Farasan town and Sayer, survive in a state of advancing disrepair (Fig. 12b). In Sayer, one abandoned house had belonged to Mohammed Ali Baloos, the father of Suleiman, the pearl merchant (c.f. above).

Issues over ownership have proved an obstacle to restoration work, but the SCTA has at least been able to fund the restoration of the former house of pearling merchant Munawwar al-Rifa'i, now owned by 'Ali al-Rifa'i-the al-Rifa'i being a prominent merchant families on the islands (Fig. 12a). Built in 1341/1921, the structure has lavish stucco-work inside and out, and a painted wooden ceiling. The restoration is part of a private dwelling, and so not open to the general public. It is nevertheless a designated archaeological site: the view of its façade is dominated by an adjacent large brown sign warning against damaging archaeological sites, hence stamping the presence of the government in this act of commemoration.

No other buildings on the islands have been restored as a heritage project. However, the historic mosque of Sheikh Yahya Ibrahim al-Najdi in Farasan town remains in use: its patron, formerly a $n \bar{a} k h \bar{o} d a$ and then a pearl merchant from one of the two most prominent merchant families on the islands, built it in 1347/1928, installing surrounds to the prayer niche (mihrāb) and pulpit (minbar) that were shipped from India (Fig. 12e). Hence maritime-relevant material culture is being conserved as part of a religious institution, rather than as a direct work of heritage conservation.

A number of maritime-related festivals are also held each year in Jizan and the Farasan Islands that are patronised by the government, and in some way maintain a connection to the sea for communities that have largely become detached from it.

The racing hüriss at al-Hafa built by Ibrahim Bilghaith are used during the end-ofRamadan Eid al-Fitr festival to race from the island of Hibar, almost $13 \mathrm{~km}$ west of Jizan, back to the al-Hafa harbour. The race, involving a crew of three and a fleet of some nine boats, takes about an hour to one-and-half hours to complete. The sailing skills required are 
limited: the race can be done on a single tack, with the destination on the mainland in view at all times. Nevertheless, it is attended by the governor of the province or his deputy.

On the Farasan Islands, a natural phenomenon has long formed the basis for local celebrations: this is the annual aggregation of thousands of longnose parrot fish (Ar. harid; Lat. Hipposcarus harid) in a spur of the Hadar bay immediately after a full moon in March or April (Gladstone 1996: 483-485). The event is accompanied by the reef's release of coral spawn, which can be detected in the air as a smell known to local people as $b \bar{u} s \bar{\imath}$ : they believe that it is this that attracts the fish (Muftāh 1426/2005: 124). Traditionally, people caught the fish with nets, and the event was accompanied with sea songs and dance (Muftah1426/2005: 120-131): newly wedded couples attended in wedding costumes from India. Today, the event is patronised by the governor of Jizan province, advertised as a domestic tourist event, and covered by state television. Women no longer attend as before and, rather than being caught using nets, the fish are driven into metal cages erected in the shallows and collected in a free-for-all.

A less obviously maritime festival takes place in Jizan: one celebrating the mango harvest in May. Mangoes (Mangifera indica) were only introduced in 1982 by the Ministry of Agriculture when trade conducted by sailing dhows was at an end. In the days of sail, local men, women and children would gather on the beach to mark the sailors' departure and return. All this survives in the memories of Jizanis. This has given way to the mango festival, in that the mango tree was introduced from India and the sailors and pearl divers that were once engaged at sea either became fishermen or left the coast to work in agricultural lands nearby. The festival gathers people to celebrate the harvest with themes of song and dance traditionally connected with both maritime and terrestrial folklore, providing the public with "an array of entertainment in the form of children's shows, displays of traditional folk practices, plays and all manner of competitions."

\section{Discussion and Conclusion}

Speaking of his native Kuwait, Yacoub al-Hijji (2010: 130) says of the transformations wrought by the coming of the oil industry that, by the 1960s, "its people had become so reoriented away from their maritime livelihoods to the desert oil rigs and government jobs, that the sea had been rendered little more than a body of water to swim and fish in". These changes had in turn "rendered obsolete, with obvious and irresistible force, an entire traditional system of manual skills, maritime knowledge, commercial practices and cultural forms built up over centuries" (al-Hijji 2010: 134). Similar transformations have taken place across the oil-producing states of Arabia-even, in the case of Jazan, in a province far from the centres of the industry.

Al-Hijji's notion of "obsolescence" is apposite to our consideration of the survival of a maritime cultural memory in Jazan and the Farasan Islands. As Jan Assmann (2006: 87) puts it, the past is "the decisive resource for the consciousness of national identity" - and indeed other foci of identity such as family, settlement and region. For most Arab states of the Arabian-Persian Gulf, maritime aspects of the past have been a key element in the construction of that consciousness (Agius 2005: 203-219). Traditional sailing vessels and maritime activities have featured widely on public monuments, banknotes, postage stamps and the logos of public and private companies in reinforcement of this narrative. Kuwait, Bahrain, Sharjah and Oman have created maritime museums, and others are planned for

${ }^{42}$ http://www.saudigazette.com.sa (accessed 16 March 2015). 
Qatar and Abu Dhabi. National day events are often closely tied to maritime festivals, including parades of traditional sail and racing. For all of these polities, national narratives have been built around the historical maritime involvements of the ruling families and the wider indigenous communities they rule. Promotion of the narrative of a virtuous maritime past through what Nora (1989) calls "lieux de mémoire" has therefore been contiguous with the building of national identity following independence from Britain in the 1960s and 1970s.

Maritime identity and national narratives have not been such easy bedfellows in Saudi Arabia. The ruling Al Saud family originates in the Najd, in central Arabia, and so does not have a ready cultural connection with the sea. Meanwhile, seafaring communities on the Arabian-Persian Gulf tend to be Shì a, and so are in confessional and political tension with the Sunnī Al Saud and its religious establishment. And on the Red Sea, the kingdom's provinces were until 1924-5 part of the Hashemite Kingdom of the Hejaz. Inevitably, both of these coastal regions have rich maritime pasts that could form the basis for identity formation-but only in distinction to the Najdi seat of power. For this reason, we propose, maritime narratives have not, historically, been promoted as part of the identity narrative of the Saudi state, since they have more potential to be divisive than uniting. The irrelevance of such narratives to the Wahhabi world-view, meanwhile, cannot have helped. Finally, the fact that a large part of the Saudi population lives far from the sea has further led to the marginalisation of maritime cultural themes in national consciousness building (General Authority for Statistics 1428/2007: 61).

Involvement by the Saudi state in maritime-focused heritage initiatives has been limited as a result of all these factors. In Jizan and the Farasan Islands, it has been restricted to a small number of ahistorical public art installations, either depicting globalised imagery of the sea or un-interpreted and ahistorical representations of traditional watercraft. Official presentations of heritage objects are, as we have seen, extremely limited. State involvement in locally targeted maritime-heritage activity can otherwise be seen only in the patronage, co-option and adaptation of small existing local festivals. What we have seen, overwhelmingly, is an obsolescence of maritime knowledge as communities have turned away from historic maritime practices - the original millieux de mémoire (Nora 1989: 7)— and, with that turning away, a parallel obsolescence of that heritage with respect to the narrative-creating priorities of Saudi heritage agencies. Where the local municipality was active in the creation of maritime symbolism - for example on the traffic interchanges of Jizan - these tended towards symbols of maritime modernity or non-specific abstraction away from the human experience of the sea, not least for religious reasons of non-representation of the human form. This amounts to an active forgetting of large swathes of the maritime past on the state level, a process that serves the centralising interests of the state insofar as this forgetting removes from public discourse the material reference points of what Aleida Assmann (2010: 106) calls "the active working memory of a society that defines and supports the cultural identity of a group." By being less maritime in their knowledge and memory, Farasanis and Jizanis become more Saudi.

In the absence of significant state resourcing, the capacity of small communities in Jizan and the Farasan Islands to actively remember the maritime past through retention, conservation and presentation of tangible heritage has proved limited. "We are what we keep", as Terry Cook (2011: 173) expresses it: "The obverse is true as well: we keep what we are." Cook is referring to decisions by institutions of the state with respect to the preservation or otherwise of material in archives. But the same can also be said of the loss within communities of "maritimity" - to use Tuddenham's neologism (2010: 8) -in terms both of the material culture and memory of seafaring activity. The loss in our region of 
interest of objects central to past maritime activity - the boats - has been the product of both active and passive forgetting. They have proved too expensive to retain once their primary economic function had lapsed, and failed to find an alternative value or utility with any agent of commemoration-personal, communal, or state - that would have enabled them to survive by other means. They were simply abandoned; consequently, they either disintegrated, or were broken up. The survival of their remains in archaeological deposits in the harsh conditions of the region will depend on serendipitous taphonomical processes. In the case of Ibrahim Bilghaith's boatyard, the remaining vessels within it are, without intervention, likely to survive no longer than the yard itself, and providing they do not obstruct economic activity.

The persistence of other maritime material culture through the transformations of the late twentieth century has been dependent on individual and occasionally communal initiatives of retention and commemoration. Historic dwellings have largely been abandoned in favour of the comforts of domestic utilities, air conditioning and vehicular access, and are falling into ruin. Objects related to more prestigious maritime-related activities, such as pearl trading, have survived within families by virtue of the social and cultural kudos they confer to their present keepers: ownership of a merchant's trading paraphernalia being a mirror of past, and therefore present, social status. In contrast, survival of items from the more lowly pearl diver's assemblage has proved more limited - to pearling baskets, knives, and diving masks, all relatively small, materially robust items having little residual economic value. The range of material culture that has "fall[en] out of the frames of attention, value and use" (Assmann 2010: 98) is therefore extensive, and with it its potential to act mnemonically as "visual clues [that] may jog the memory" with respect to the maritime past (Goody 1998: 75).

Just as regional maritime heritage and identity is struggling to find continuity and purchase through material culture-whether actively communicated or passively retained - so too the intergenerational mechanisms of maritime memory transmission are by no means secure. Al-Hijji's notion of obsolescence is again relevant here. The biologically retained corpus of maritime skills, knowledge, practices and forms to which he refers were in the past transmitted through intergenerational participation in activities such as sailing, pearling, and fishing within a culturally construed maritime landscape. As Freire (2014: 145) says, such landscapes "center on questions of continuity, social dynamics and mental and natural perceptions of a region." With the discontinuation of these activities, either entirely or at least in their previous forms, the mechanisms of intergenerational transmission have been lost, and with it the knowledge that forms the basis of intangible heritage. Elderly boatbuilders, dhow owners, captains, seafarers, fishermen, pearl divers and traders spoke to the authors with pride about their past lives, but these are not always being transmitted. When we interviewed Sheikh Muhammad Isa Muhammad Aqili at his home in Farasan town, two of his grandsons video-recorded the encounter on their smartphones. "He has never talked to us about these things," one of them told us afterwards. With such "principle loci" (Olick et al. 2011: 311) of the transmission of cultural memory failing, the loss of memory of past maritimity appears imminent in Jazan and the Farasan Islands, and justifies the documentation at least of surviving fragments of its memory, even if this forms only a passive archive-recorded by eminent local people such as Ibrahim Muftah and the present authors - rather than as a canonical discourse in the active social memory of the region (Assmann 2010: 97-98).

Of course, the authors' relatively transient encounter with the memories and material souvenirs of their informants cannot claim to be fully informative or definitive of the state of maritime recollection and heritage formation. The authors' status as outsiders, the 
relative brevity of our visits, and the interview-based nature of the encounters constrained our ability to gather memories and understand the place that maritime heritage is taking with local narratives of the past. Our questions were inevitably derived from our preexisting interests, for example in the maritime lexicon, boatbuilding traditions, pearling practices, etc., which can only have set the direction of our encounters, and the information we received. The fact that we were a mixed gender group, working together, meant that we only had the possibility of interviewing men: the experiences of women and children while their menfolk were at sea were therefore not accessible to us. And while we became aware when our informants spoke with pride, we cannot know what narratives shame, taboo, or fear of social or official censure, prompted them to withhold. Hence both authors and informants were in their own way active in normatising and circumscribing the memories that have found their way into this narrative.

It is clear from our encounters that recalled memory of the maritime past, at least within the interview contexts in which the authors operated, was in many cases taking shape around narrative tropes and material assemblages. Informants talked with relative ease around such subjects and object collections as the relative poverty and indebtedness of pearl divers, the pearl trader's kit, the types of nacre shell dived for, etc. But informants tended to become vague or mutually contradictory when it came to the detail of more abstract and complex issues such as the economic system underpinning the pearling season. One important aspect of people's maritime recollections is the landscape within which past activities took place—as Westerdahl $(1992$; 2011) puts it: “... human utilization (economy) of maritime space by boat: settlement, fishing, hunting, shipping and its attendant subcultures" (1992: 5). As that utilisation has receded with the cessation of many aspects of past maritime life, so too the memory of that landscape has receded. Landscape, and landscape-based navigational knowledge, is particularly difficult to recollect and reproduce in interview outside of its practiced context, since so much is subject to sensory stimuli provided by the environment in question. ${ }^{43}$ With many contemporary fishermen using GPS and motorised vessels, past knowledge about wind- and current-based propulsion, way-finding and position fixing has become redundant. Interviewees recalled voyage destinations - to Dahlak, the East Africa coast of the southern Red Sea, Aden, Basra and western India - but little on route or seamanship. Others recalled a small number of names or locations of broad locations of pearling beds, but recounted little more. Ibrahim Muftah, for example, acknowledged the existence in the past of star-based navigation, but could name only three constellations that constituted part of that knowledge.

Much research remains to be done to document the material and intangible vestiges of maritime life in this region and the wider Red Sea and Arabian Peninsula. The authors are preparing monographs on the life of the Red Sea dhows, a cultural history of seaborne exploration (Agius) and boatbuilding traditions in the southern Red Sea and Gulf of Aden (Cooper et al., forthcoming), as well as an article on songs of the sea, including some encountered during the Farasan fieldwork (Agius). However, the wider region's deteriorating political situation has already curtailed plans for further work, for example in Yemen, and threatens to do so further for the foreseeable future. Other potentially fruitful areas, including Somaliland and Eritrea, remain difficult to access. With much being lost in terms of memories, practices and material culture as communities and economies change, the chances for researchers to record them are fading fast.

${ }_{43}$ For a discussion of the importance of location to the outcomes of the interview process, see Herzog 2012. 
Acknowledgments The authors wish to thank Secretary-General of the Saudi Commission for Tourism and Antiquities (SCTA), HH Prince Salman bin Sultan for his kind invitation to the MARES team to work in Jizan and the Farasan Islands. Thanks are also due to Professor Ali al-Ghabban, SCTA Vice President for Antiquities and Museums; Professor Abd al-Aziz al-Ghazzi, SCTA Head of Research and Projects; Dr Zahir Othman of the Turath Foundation; Mr. Muhammad Al al-Sheikh of the Riyadh Development Authority and Farasan Hotel; Engineer Abd al-Rahman Bin Muhammad Abd Al Haqq, Governor of Farasan Islands; Sheikh Muhammad Hadi al-Rajhi of Greater Farasan; Sheikh Muhammad Abd Allah al-Rajhi of Khutub on Segid Island; and MARES consultant Mr. Peter Harrigan, founding director of Medina Publishing. Fieldwork was facilitated by SCTA colleagues Dr. Faisal Al-Toumaihi and Mr. Abdo Isa Aqili. We are indebted to Farasan Islands historians Mr. Ibrahim Muftah and Mr. Ibrahim Sayyadi, who provided invaluable advice on Farasani history and archaeological sites, and to our many interviewees. The MARES Project was funded by the Golden Web Foundation, a UK educational charity, and the fieldwork supported by King Abdulaziz University, Jeddah, and the Seven Pillars of Wisdom Trust, UK. We are also grateful to the peer reviewers who scrutinized this paper.

Funding This study was funded by the Golden Web Foundation (UK registered charity number 1100608), with additional support from the Seven Pillars of Wisdom Trust (UK registered charity number 208669).

\section{Compliance with Ethical Standards}

Conflict of Interest The authors declare that they have no conflict of interest.

Open Access This article is distributed under the terms of the Creative Commons Attribution 4.0 International License (http://creativecommons.org/licenses/by/4.0/), which permits unrestricted use, distribution, and reproduction in any medium, provided you give appropriate credit to the original author(s) and the source, provide a link to the Creative Commons license, and indicate if changes were made.

\section{References}

Agius DA (2002) In the Wake of the Dhow: the Arabian Gulf and Oman. Ithaca, Reading

Agius DA (2005) Seafaring in the Arabian Gulf and Oman: the People of the Dhow. Kegan Paul, London Agius DA (forthcoming) The life of the Red Sea Dhow: a cultural history of seaborne exploration in the Islamic World. I.B. Tauris, London

Agius DA, Cooper JP, Jansen van Rensburg J, Zazzaro C (2010) The dhow's last redoubt? Vestiges of wooden boatbuilding traditions in Yemen. Proc Semin Arab Stud 40:71-84

Agius DA, Cooper JP, Zazzaro C (2014) The maritime heritage of Yemen: a focus on traditional wooden 'dhows'. In: Agius DA, Gambin T, Trakadas A (eds) Ships, saints and sealore: cultural heritage and ethnography of the Mediterranean and the Red Sea. Archaeopress, Oxford, pp 143-158

Al-Hijji YY (2010) Kuwait and the sea: a brief social and economic history. Arabian Publishing, London

Al-Hubaishi \& Müller-Hohenstein (1984) An introduction to the vegetation of Yemen: ecological basis, floristic composition, human influence. Deutsche Gesellschaft für Technische Zusammenarbeit, Eschborn

Al-Mas'ūdī AAR (1983) In: Dāghir YA (ed) Murūj al-dhahab wa ma ‘ādin al-jawhar, vol 4. Dār al-Andalus, Beirut

Al-Nafie AH (2008) Phytogeography of Saudi Arabia. J Biol Sci 15(1):159-176

Al-Qādī MA (1928) Kitāb al-Al-la 'àli'. al-Maṭba'a al-Hijāziyya, Bombay

Anonymous (1946) Western Arabia and the Red Sea. H.M. Stationery Office, Oxford: Oxford University Press, London

Assmann J (1995) Cultural memory and cultural identity. N German Crit 65:125-133

Assmann J (1997) Moses the Egyptian: the memory of Egypt in Western Monotheism. Harvard University Press, Cambridge

Assmann J (2006) Religion and cultural memory. Stanford University Press, Stanford

Assmann A (2010) Canon and archive. In: Erll A, Nünning A (eds) Cultural memory studies. An international and interdisciplinary handbook. Walter de Gruyter, Berlin, pp 97-108

Bailey GN, Flemming N, King GCP, Lambeck K, Momber G, Moran LJ, Al-Sharekh A, Vita-Frinzi C (2007a) Coastlines, submerged landscapes, and human evolution: the Red Sea Basin and the Farasan Islands. J Island Coast Archaeol 2:127-160 
Bailey G, AlSharekh A, Flemming N, Lambeck K, Momber G, Sinclair A, Vita-Finzi C (2007b) Coastal prehistory in the Southern Red Sea basin, underwater archaeology, and the Farasan Islands. Proc Semin Arab Stud 37:1-16

Bailey GN, Meredith-Williams MG, Alsharekh AM (2013) Shell Mounds of the Farasan Islands, Saudi Arabia. In: Bailey GN, Hardy K, Camara A (eds) Shell energy: mollusc shells as coastal resources. Oxbow Books, Oxford, pp 241-254

Blue L, Whitewright J, Cooper JP (forthcoming) The Ubiquitous Hūrī: Maritime Ethnography, Archaeology and History in the western Indian Ocean. In: Proceedings of the thirteenth symposium on boat and ship archaeology

Bosch E (1989) Seashells of Southern Arabia. Motivate Publishing, Dubai

Carter JRL (1979) Leading merchant families of Saudi Arabia. Scorpion Publications, London

Carter RA (2012) Sea of pearls: seven thousand years of the industry that shaped the Gulf. Arabian Publishing, London

Central Department of Statistics and Information, Kingdom of Saudi Arabia (2004) Highlights: population \& housing census $1425 \mathrm{H}$. http://www.cdsi.gov.sa/2010-07-31-07-00-05/catview/31-/138-/451425-2004. Accessed 30 Dec 2015

Cook T (2011) 'We are what we keep; we keep what we are': archival appraisal past, present and future. J Soc Arch 32(2):173-189

Cooper JP, Zazzaro C (2012) A Stone Anchor from the Farasan Islands, Saudi Arabia. Int J Naut Archaeol 41(2):408-409

Cooper JP, Zazzaro C (2014) The Farasan Islands, Saudi Arabia: towards a chronology of settlement. Arab Archaeol Epigr 25:147-174

Cooper JP, Zazzaro C, Agius DA (forthcoming) Boatbuilding in the Southern Red Sea: tradition and transition

Davies S, Morgan E (2002) Red Sea pilot. Imray Laurie Norie and Wilson, Huntingdon

Donald M (1991) The origins of the human mind. Harvard University Press, Cambridge

Durand P (1986) White Meranti, Yellow Meranti, Yellow Seraya, Yellow Lauan. Revue Bois et Forêts des Tropiques 214(4):48-64

El-Demerdash MA (1996) The vegetation of the Farasan Islands, Red Sea, Saudi Arabia. J Veg Sci 7:81-88

Freire J (2014) Maritime cultural landscape: a new approach to the Cascais coastline. J Marit Archaeol 9 (1): 143-157

General Authority for Statistics (1428/2007). Highlights: demographic survey 1428H (2007). Ministry of Economy \& Planning, Riyadh

Gladstone W (1996) Unique annual aggregation of longnose parrotfish (Hipposcarus harid) at Farasan Island (Saudi Arabia, Red Sea). Copeia 1996(2):483-485

Goody J (1998) Memory in oral and literate traditions. In: Fara P, Patterson K (eds) Memory. Cambridge University Press, Cambridge, pp 73-94

Gottwald HP (1968) L'identification et l'appellation des bois de "Lauan” et de "Meranti.". Revue Bois et Forêts des Tropiques 121:35-45

Hawkins CW (1977) The dhow: an illustrated history of the dhow and its world. Nautical Publishing, Lymington

Herzog H (2012) Interview Location and its Social Meaning. In: Gubrium JF, Holstein JA, Marvasti AB, McKinney KD (eds) The SAGE handbook of interview research: the complexity of the craft, 2nd edn. Sage, Los Angeles, pp 207-217

Hornell J (1942) A tentative classification of Arab Sea-Craft. The Mariner's Mirror 28(1):11-40

Hubaylī MMA, Hubaylī LMA (2010 1431 A.H./) Jazīrat Farasān: al-tārīkh wa 1-siyāḥa. Mațābi Jālān

Jansen van Rensburg J (2010) The Hawārī of Socotra, Yemen. Int J Naut Archaeol 39(1):99-109

Khalil HM (2012) Pliocene-Pleistocene stratigraphy and macrofauna of the Farasan Islands, South East Red Sea, Saudi Arabia. Arab J Geosci 5(6):1223-1245

Lebkicher R, Rentz G, Steineke M (1960) Aramco handbook. Arabian American Oil Company, New York

Leroi-Gourhan A (1993) Gesture and speech. MIT Press, Cambridge

Londres A (2008 (1931)) Pêcheurs de Perles. Motfs, Dijon-Quetigny

Mabberley DJ (2008) Mabberley's plant book: a portable dictionary of plants, their classification and uses. Cambridge University Press, Cambridge

Megill A (2007) Historical knowledge, historical error: a contemporary guide to practice. Chicago University Press, Chicago

Migahid M, Hammouda MA (1974) Flora of Saudi Arabia. King Saud University, Riyadh

Miran J (2009) Red sea citizens: cosmopolitan society and cultural change in Massawa. Indiana University Press, Bloomington

Moore A 1970 (1925) Last days of mast \& sail. David \& Charles, Newton Abbott 
Muftāḥ I'AA (1426/2005) Farasān: Al-nās, al-baḥr, wa 1-tārīkh. Sharikat al-Madīna 1-Munawwara lil-Ṭibā'a wa 1-Nashr, Jeddah

Nora P (1989) Between memory and history: Les Lieux de Mémoire. Trans by Marc Roudebush. Representations 26:7-25

Olick JK, Vinitzky-Seroussi V, Levy D (2011) Media and Modes of Transmission. In: Olick JK, VinitzkySeroussi V, Levy D (eds) The collective memory reader. Oxford University Press, Oxford, pp 311-313

Prados E (1996a) Traditional fishing craft of the Tihamah and Southwestern Arabian Coast. Am Neptune 56:89-115

Prados E (1996b) Huris, sanbuqs and the boatbuilders of the Yemen. Woodenboat 131:50-56

Prados E (1997) Indian Ocean littoral maritime evolution: the case of the Yemeni huri and sanbuq. Mariner's Mirror 83(2):185-198

Provençal P (2010) The Arabic plant names of Peter Forsskål's flora Aegyptiaco-Arabica. The Royal Danish Academy of Sciences and Letters, Copenhagen

Schörle K (2014) Pearls, power and profit: mercantile networks and economic considerations of the pearl trade in the roman empire. In: Maiuro M, De Romanis F (eds) A tale of two worlds: comparative perspectives on Indo-Mediterranean commerce (I-XVII c.). Columbia University Press, New York

Semaan L (2015) From tree to plank: a multidisciplinary approach to the study of wood use in boatbuilding in the Red Sea. University of Exeter Ph.D. thesis

Sharabati D (1981) Saudi Arabian Seashells: selected Red Sea and Arabian Gulf Molluscs. Kegan Paul International, Henley-on-Thames

Sharabati D (1984) Red Sea Shells. KPI, London

Sturman N, Homkrajae A, Manustrong A, Somsa-ard N (2014) Observations on Pearls Reportedly from the Pinnidae Family (Pen Pearls). Gems Gemol 50(3):202-215

Tibbetts GR (1981 (1971)) Arab Navigation in the Indian Ocean before the Coming of the Portugese: being a Translation of Kitāb al-fawā'id fī uṣūl al-baḥr al-qawā'id of Aḥmad b. Majid al-Najdī. Royal Asiatic Society, London

Tuddenham DB (2010) Maritime cultural landscapes, maritimity and quasi objects. J Marit Archaeol 5(1):516

Vine P (1986) Red Sea Invertebrates. Immel Publishing, London

Westerdahl C (1992) The maritime cultural landscape. Int J Naut Archaeol 21(1):5-14

Westerdahl C (2011) The maritime cultural landscapes. In: Catsambis A, Ford B, Hamilton DL (eds) The Oxford handbook of maritime archaeology. Oxford University Press, Oxford, pp 733-762

Williams MGM (2010) Shell mounds of the Farasan Islands. Proc Semin Arab Stud 40:357-366

Wood JRI (1997) A handbook of the Yemen Flora. Royal Botanic Gardens, Kew, London 